PRZEGLĄD NAUK HISTORYCZNYCH 2017, R. XVI, NR 2

http://dx.doi.org/10.18778/1644-857X.16.02.03

ZBigniew ANUSIK

UNIWERSYTET ŁÓDZKI

\title{
Rzeczpospolita wobec Rosji w ostatniej fazie obrad Sejmu Wielkiego (1791-1792)
}

Streszczenie. Po uchwaleniu Konstytucji 3 maja ułożenie stosunków z Rosją było najważniejszą kwestią $z$ punktu widzenia bezpieczeństwa Rzeczypospolitej. Widząc wygasanie pomyślnej dla państwa polsko-litewskiego koniunktury w stosunkach międzynarodowych, przywódcy Sejmu Wielkiego zasugerowali Stanisławowi Augustowi dokonanie zwrotu ku Rosji. To z ich inicjatywy król wprowadził do Straży Praw kilku stronników dworu petersburskiego. Nie pociagnęło to jednak za sobą reorientacji polskiej polityki zagranicznej. Umocniwszy swoją pozycję, Stanisław August zwlekał $z$ nawiazaniem bezpośrednich rozmów $z$ cesarzową. Był przekonany, że wystarczy nie prowokować Rosjan i łagodzić wszelkie konflikty wewnętrzne, żeby uniknąc rosyjskiej interwencji w wewnętrzne sprawy Rzeczypospolitej. Założenie to okazało się błędne. Wbrew twierdzeniu ogromnej większości historyków polskich, którzy uważali, że rosyjska interwencja w Polsce była $z$ góry przesązona, na dworze petersburskim do ostatniej chwili trwały spory i dyskusje dotyczace kształtu polityki wobec państwa polsko-litewskiego. Część doradców Katarzyny II była zdania, że bez ostatecznego porozumienia $z$ dworami niemieckimi nie należy zaczynać wojny z Rzeczapospolitą, gdyż będzie ona ciężka, długotrwała i kosztowna. Namowy polskich malkontentów sprawiły jednak, że ostatecznie zwyciężyła, lansowana przez faworyta cesarzowej - Płatona A. Zubowa, koncepcja rozpoczęcia działań zbrojnych bez oglądania się na stanowisko Wiednia i Berlina. Bierność dyplomatyczna okazała się fatalnym błędem polskiego króla i jego doradców. Równie błędna była koncepcja prowadzenia wojny w ograniczonym tylko zakresie. Słaby opór polskich armii umacniał bowiem pozycję faworyta cesarzowej. Już w trakcie działań wojennych, po nadejściu do Petersburga listu Stanisława Augusta do Katarzyny II, grupa przeciwników wojny na dworze rosyjskim podjęła ostatnią próbę przerwania działań zbrojnych i rozpoczęcia rozmów $z$ władca Rzeczypospolitej. Sukcesy wojsk cesarzowej, które w ślad za wycofujacymi się Polakami zmierzały szybko w kierunku Warszawy działały jednak na korzyść zwolenników zbrojnej interwencji. Król i jego doradcy zbyt szybko przestali

* Wydział Filozoficzno-Historyczny, Instytut Historii, Katedra Historii Nowożytnej, e-mail: zanusik@uni.lodz.pl. 
wierzyć w możliwość odniesienia zwycięstwa i skapitulowali w chwili, kiedy wciąż istniały szanse na kontynuowanie wojny, której przedłużenie o kilka tygodni mogło skłonić cesarzową do wyrażenia zgody na rozpoczęcie negocjacji pokojowych. Był to fatalny błąd polityczny, który okazał się w konsekwencji początkiem końca pierwszej Rzeczypospolitej.

Słowa kluczowe: Sejm Wielki, Konstytucja 3 maja, Straż Praw, polityka zagraniczna Rzeczypospolitej, stosunki polsko-rosyjskie w latach 1791-1792.

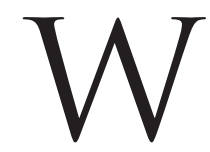

dziesięcioleciu poprzedzającym zwołanie Sejmu Wielkiego dojrzewał w Rzeczypospolitej poważny kryzys wewnętrzny, któremu towarzyszył znaczacy wzrost nastrojów niezadowolenia $z$ rosyjskiego protektoratu. Dażenia szerokich kręgów społeczeństwa szlacheckiego, wyrażane expressis verbis przez grupę niezależnych posłów opozycyjnych na sejmach z lat 1778-1786, sprowadzały się już wówczas do formułowania postulatów o konieczności obrony godności narodowej, samodzielnego rozwiazywania (choćby tylko w granicach gwarancji traktatowych) problemów wewnętrznych, podjęcia natychmiastowych działań zmierzajacych do wzmocnienia armii oraz przeprowadzenia koniecznych reform bez oglądania się na zgodę Rosji. Prowadziło to w konsekwencji do upowszechnienia antyrosyjskich tendencji wśród szlachty i zmusiło "oświecony" odłam magnackich przywódców opozycji do przeorientowania własnego programu politycznego. Ta reorientacja znalazła swój wyraz w republikańsko-patriotycznym programie politycznym Czartoryskich i Potockich oraz w podjecciu przez nich szlacheckiego hasła obrony suwerenności narodu i państwa. Wydaje się, że popularność patriotycznych postaw nie była bynajmniej wynikiem odgórnych zabiegów. Wręcz przeciwnie, sądzić można, że to przywódcy obozu puławskiego poszli za głosem niezależnych posłów, reprezentujących przekonania znacznej części społeczeństwa szlacheckiego, co zdaje się też tłumaczyć bezprzykładny sukces opozycji w początkach obrad Sejmu Wielkiego ${ }^{1}$.

${ }^{1}$ Por. A. Stroynowski, Patriotyczne wystapienia opozycji na sejmie 1778 r., „Acta Universitatis Lodziensis”, Folia Historica 19, 1984, s. 178-179; id e m, Sejmowa opozycja antykrólewska w czasach Rady Nieustajacej (kryteria klasyfikacji), „Acta Universitatis Lodziensis”, Folia Historica 18, 1984, s. 26; W. Szczy gi els ki, Oświecony elitaryzm w Polsce, „Zeszyty Naukowe Uniwersytetu Łódzkiego”, Ser. I, z. 4, 1976, s. 120; J. Michals ki, „Warszawa”, czyli o antystołecznych nastrojach w czasach Stanisława Augusta, [w:] Warszawa XVIII wieku, z. 1, Warszawa 1972, s. 30-31; Z. Anusik, Rzeczpospolita wobec wojny wschodniej (1787-1792) i wojny szwedzko-rosyjskiej (1788-1790), [w:] Polska wobec wielkich konfliktów w Europie 
Początki obrad tego sejmu przyniosły całkowity triumf, szermującej antyrosyjskimi hasłami opozycji antyregalistycznej, określanej mianem patriotów. Jej przywódcy, zdecydowawszy się na porozumienie $z$ Prusami, jawnie wystapili przeciwko dyktatowi ambasadora rosyjskiego w Warszawie, Ottona von Stackelberga, broniącego nienawistnego im systemu Rady Nieustajacej. W celu przeforsowania swojego programu, część $z$ nich gotowa była nawet odwołać się do pruskiej pomocy wojskowej. Stanowiło to upragniony cel dworu berlińskiego, który zmierzał w tym czasie do dokonania zaboru części ziem Rzeczypospolitej².

Bardzo szybko załamały się też fundamenty rosyjskiej przewagi w Polsce. Dnia 13 października 1788 r. rezydent pruski w Warszawie, Ludwig von Buchholtz, w złożonej w imieniu swego króla nocie, wykazał antypruski charakter projektowanego od jesieni 1787 r. przymierza polsko-rosyjskiego. Równocześnie zaoferował sejmujacym stanom, alternatywny w stosunku do propozycji rosyjskich, sojusz z Fryderykiem Wilhelmem II. W tej sytuacji Katarzyna II przestała nalegać na sfinalizowanie traktatu z Rzeczapospolita, a i Stanisław August zaczał wattpić w szanse jego przyjęcia przez sejm. Dnia 20 października podjęto uchwałę o powołaniu stutysięcznej armii. W dniu 3 listopada zniesiono Departament Wojskowy Rady Nieustającej i zwierzchnictwo nad armia powierzono uzależnionej bezpośrednio od sejmu Komisji Wojskowej. Dnia 19 listopada, pod wpływem nacisków obozu patriotycznego, Buchholtz zrzekł się $\mathrm{w}$ imieniu swojego monarchy gwarancji polskich wolności. Dwór berliński uznał jedynie, oparta na traktacie z 1775 r., gwarantowaną wraz z Rosją całość Rzeczypospolitej. W dniu 29 listopada sejm ogłosił się nieustajacym, by od dnia zlikwidowania Rady Nieustajacej - 19 stycznia 1789 r. - objąć bezpośrednie rządy nad krajem³ ${ }^{3}$.

nowożytnej. $Z$ dziejów dyplomacji $i$ stosunków międzynarodowych $w$ XV-XVIII wieku, red. R. Skowron, Kraków 2009, s. 148-149.

2 Por. M. Kucharski, Działalność dyplomacji polskiej $w$ Berlinie $w$ latach 1788-1792, Katowice 2000, s. 24-25; Z. A nu sik, Stosunki polsko-pruskie w dobie Sejmu Czteroletniego. Kilka refleksji w zwiazku z ksiażka Macieja Kucharskiego, „Przegląd Nauk Historycznych” 2003, R. II, nr 1 (3), s. 208-209; id e m, Rzeczpospolita wobec wojny..., s. 150-151.

3 Por. W. Kal in ka, Sejm Czteroletni, wyd. 4, t. I, cz. 1, Kraków 1895, s. 243-250, 256-265, 293-299; W. Szczygielski, Krytyka parlamentarna Rady Nieustajacej $w$ poczatkach obrad Sejmu Wielkiego a problem konstytucyjnej reformy władz wykonawczych państwa, „Przegląd Nauk Historycznych” 2003, R. II, nr 2 (4), s. 67-110; Z. Anusik, Wznowienie stosunków dyplomatycznych polsko-szwedz- 
Najistotniejsze znaczenie dla przyszłości dzieła sejmowego miała jednak postawa dotychczasowej protektorki Rzeczypospolitej, czyli Rosji. Jak się miało okazać, dyplomacja austriacka, kierowana przez ostrożnego i wytrawnego polityka, jakim był kanclerz Wenzel Anton von Kaunitz, nakłoniła dwór petersburski do zajęcia tolerancyjnej postawy wobec emancypacyjnych dążeń Polaków. Kaunitz udowadniał, że Prusom chodzi przede wszystkim o sprowokowanie wojny, która w owym momencie byłaby dla obu wojujących $z$ Turcją dworów bardzo niebezpieczna. Katarzyna II okazała się skłonna do zaakceptowania sugestii wysuniętych przez jej sojusznika i w związku $z$ tym, zajęła stanowisko pozornie obojętne w stosunku do wewnętrznych wydarzeń w Rzeczypospolitej. Co jednak z polskiego punktu widzenia ważniejsze, zastosowała się do popartych przez Prusy żądań polskich (po raz pierwszy sformułowanych już 15 listopada 1788 r.), wycofujac $z$ terytorium Rzeczypospolitej wszystkie swoje oddziały (decyzję w tej sprawie podjęła cesarzowa w maju 1789 r.), a w późniejszym terminie również magazyny wojskowe ${ }^{4}$.

Korzystając $z$ pomyślnej koniunktury na arenie międzynarodowej, już w pierwszych tygodniach obrad patriotyczna większość sejmowa przypuściła generalny atak na całokształt dotychczasowej organizacji stosunków Rzeczypospolitej z zagranica. Przystapiono też do demontażu dotychczasowej formy rządu. Ataki na Radę Nieustająca rozpoczęto od krytyki i kolejnej likwidacji jej magistratur. Po wspomnianym zniesieniu Departamentu Wojskowego Rady Nieustającej przyszła kolej na jej Departament Interesów Cudzoziemskich. Dnia 9 grudnia 1788 r. sejm wyznaczył nowych posłów do sześciu najważniejszych stolic europejskich. Wyrazem ostatecznego zwycięstwa opozycji i odebrania królowi kontroli nad resortem spraw zagranicznych było jednak dopiero utworzenie w dniu 18 grudnia „Deputacji do ułożenia instrukcji urodzonym posłom za granicę i dozoru negocjacji z dworami zagranicznymi”. W ten

kich u progu obrad Sejmu Czteroletniego, „Acta Universitatis Lodziensis”, Folia Historica 49, 1993, s. 79-80; id e m, Rzeczpospolita wobec wojny..., s. 151-152.

${ }^{4}$ Por. W. Kalinka, op. cit., t. I, cz. 2, Kraków 1895, s. 497-503; R.H. Lord, Drugi rozbiór Polski, Warszawa 1973, s. 75-79; J. Michalski, Dyplomacja polska w latach 1764-1795, [w:] Historia dyplomacji polskiej, t. II (1572-1795), red. Z. Wójcik, s. 614; Z. A nu sik, Wznowienie stosunków..., s. 80; i d e m, Rzeczpospolita wobec wojny..., s. 152; D. Naw rot, Działania dyplomacji polskiej $w$ Wiedniu $w$ latach 1788-1792, Katowice 1999, s. 26-29. 
sposób sejm przejałł oficjalnie ster polityki zagranicznej i nadzór nad działalnościa polskiej służby dyplomatycznej ${ }^{5}$.

Od chwili powołania Deputacji Interesów Zagranicznych największy wpływ na jej prace wywierali obaj marszałkowie konfederacji, czyli Stanisław Małachowski i Kazimierz Nestor Sapieha, a także Ignacy Potocki i biskup kujawski Józef Ignacy Rybiński. Właściwym inspiratorem i kierownikiem polityki zagranicznej sejmu starał się być Ignacy Potocki, który w czasie istnienia tej magistratury utrzymywał odrębną od oficjalnej korespondencję $z$ polskimi placówkami dyplomatycznymi. Należy jednak pamiętać również o tym, że będąc jednym $z$ najbardziej wpływowych członków Deputacji, prowadził on w sposób niesłychanie ostrożny działalność w zakresie polityki zagranicznej państwa, konsultując swoje posunięcia w gronie najbliższych współpracowników i unikając precyzowania własnych poglądów na najbardziej nawet istotne kwestie, a prowadzona przez niego korespondencja dyplomatyczna miała $\mathrm{w}$ istocie charakter jedynie informacyjny. Wszelkie rzeczywiste decyzje polityczne zapadały bowiem w szerszym kręgu przywódców sejmowych, a związane $z$ tymi decyzjami ewentualne rozkazy do polskich placówek dyplomatycznych poza granicami kraju były przekazywane jedynie za pośrednictwem Deputacji Interesów Zagranicznych ${ }^{6}$.

Już na przełomie 1788 i 1789 r. przywódcy sejmowi podjęli decyzję o zacieśnieniu związu z Prusami, co miało być wstępem do przystapienia Rzeczypospolitej do skierowanego przeciwko dworom cesarskim trójprzymierza Wielkiej Brytanii, Prus i Holandii. Wiosna i latem 1789 r. nastapiła z kolei dekompozycja, dysponującego większościa głosów w sejmie, obozu patriotycznego. Właśnie wówczas rozeszły się bowiem drogi polityczne „prawdziwych” (spod znaku Puław i sprzymierzonych $z$ nimi braci Potockich) oraz "fałszywych” ( $z$ kręgu klienteli hetmana wielkiego koronnego Franciszka

${ }^{5}$ Por. Volumina legum [dalej: VL], t. IX, Kraków 1889, s. 57, 61-62; Z. A nu sik, Misja polska w Sztokholmie w latach 1789-1795, Łódź 1993, s. 18; id e m, Wznowienie stosunków..., s. 81; idem, Organizacja i funkcjonowanie polskiej służby zagranicznej $w$ latach 1764-1792 (próba nowego spojrzenia), „Acta Universitatis Lodziensis”, Folia Historica 58, 1996, s. 61-65; i d e m, Rzeczpospolita wobec wojny..., s. 152-153.

${ }^{6}$ Por. W. Kalinka, op. cit., t. I, cz. 1, s. 335-336; Z. Anusik, A. Stroynowski, Rybinski Józef Ignacy Tadeusz, [w:] Polski słownik biograficzny [dalej: $P S B]$, t. XXXIII, Wrocław-Warszawa-Kraków 1991-1992, s. 335-336; Z. A n u sik, Organizacja i funkcjonowanie..., s. 65-67; id e m, Misja polska..., s. 53-54; id e m, Rzeczpospolita wobec wojny..., s. 153-154. 
Ksawerego Branickiego) patriotów. Otworzyło to perspektywy na zawarcie porozumienia między „prawdziwymi” patriotami a obozem regalistycznym. Współpraca obu odłamów nowej większości sejmowej doprowadziła $\mathrm{w}$ rezultacie do podpisania $\mathrm{w}$ dniu 29 marca 1790 r. traktatu sojuszniczego między Rzecząpospolitą a Prusami. Finalizacja rokowań $z$ dworem berlińskim nastapiła w momencie, kiedy król pruski Fryderyk Wilhelm II zdecydował się na rozprawę orężna $z$ Austrią. Na dworze pruskim panowało bowiem przekonanie, że po zwycięskiej wojnie uda się uzyskać od Rzeczypospolitej dobrowolną cesję Gdańska, Torunia i części Wielkopolski. W zamian oferowano Polakom część Galicji, która zamierzano odebrać cesarzowi. Warto w tym miejscu zaznaczyć, że przywódcy Sejmu Wielkiego zaakceptowali takie rozwiąanie (liczac jednak na odzyskanie całej Galicji) i wkrótce po podpisaniu traktatu $z$ Prusami rozpoczęli przygotowania do wojny $z$ Austrią ${ }^{7}$.

Bardzo szybko okazało się jednak, że w Rzeczypospolitej przeważa obawa przed wojna, zwłaszcza że ewentualne nabytki mogły okazać się nie tak duże, jak się wcześniej spodziewano, a perspektywa bliżej nieokreślonych ustępstw terytorialnych na rzecz Prus budziła sprzeciwy. Już w końcu czerwca 1790 r. dwór berliński poinformował zresztą Warszawę, że nie będzie wymagał od Rzeczypospolitej przewidzianych w traktacie przymierza posiłków. Doradcy Fryderyka Wilhelma II doszli bowiem do wniosku, że aby uzyskać od Polaków znaczące ustępstwa terytorialne, Prusy muszą samodzielnie opanować Galicję. Sądzili, że za oddanie Polsce części opanowanego

${ }^{7}$ Por. W. Ko no pczyńs ki, Polska a Szwecja. Od pokoju oliwskiego do upadku Rzeczypospolitej 1660-1795, Warszawa 1924, s. 229-230; S. Askenazy, Przymierze polsko-pruskie, wyd. 3, Warszawa 1918, s. 62-66, 71-74; M. Ku ch ars ki, op. cit., s. 52-57, 60-67, 73-74; R.H. Lord, op. cit., s. 84-85; J. Michals ki, Dyplomacja polska..., s. 615-616; D. N aw rot, op. cit., s. 43; Z. A nu sik, Wznowienie stosunków..., s. 81, 87-92; ide m, Stosunki polsko-pruskie..., s. 211-213; id e m, Misja polska..., s. 21-24; id e m, Rzeczpospolita wobec wojny..., s. 155-160. Dodajmy w tym miejscu, że zawarcie przymierza $z$ Prusami spotkało się $z$ surowa krytyka reprezentantów tzw. krakowskiej szkoły historycznej oraz większości historyków polskich publikujacych swoje prace po II wojnie światowej. Ich zdaniem, był to kardynalny błąd polityczny, który w ostatecznym rozrachunku doprowadził do upadku Rzeczypospolitej. Opinie takie formułowali m.in. W. Kalinka, B. Dembiński, E. Rostworowski, J. Michalski i A. Zahorski. W moim przekonaniu, decyzję o związaniu się z Prusami przywódcy Sejmu Wielkiego podjęli, zdając sobie doskonale sprawę $z$ ryzyka utraty pewnych terytoriów. Sojusz ten od początku był jednak traktowany przez nich w sposób czysto pragmatyczny, będąc jedynie środkiem wiodącym do uniezależnienia się od Rosji i przeprowadzenia głębokich reform wewnętrznych. 
przez wojska pruskie zaboru austriackiego, będa mogli zażądać przynajmniej Gdańska i Torunia. Wszystkie nadzieje Prusaków na nabytki terytorialne kosztem Rzeczypospolitej zostały jednak zniweczone wraz $z$ podpisaniem w Reichenbachu 27 lipca 1790 r. austriacko-pruskiej konwencji pokojowej. Nowy cesarz niemiecki i władca Austrii - Leopold II zgodził się bowiem niespodziewanie na zawarcie pokoju z Turcja na zasadach status quo ante. Dodajmy w tym miejscu, że konwencja reichenbachska stanowiła całkowite zaskoczenie dla przywódców sejmowych w Warszawie. Równie zaskoczony wynikiem rozmów $z$ wysłannikami cesarza był jednak sam Fryderyk Wilhelm II, który uważał wybuch wojny z Austria za przesązony $^{8}$.

Wieści z Reichenbachu zostały źle przyjęte w Warszawie. Przywódcy Sejmu Wielkiego obawiali się bowiem, że wygaszenie konfliktu prusko-austriackiego może odebrać rację bytu przymierzu z 29 marca 1790 r. Dlatego też zrobili wszystko, aby nadać temu sojuszowi wydźwięk antyrosyjski i uczynić go atrakcyjnym dla pruskiego partnera. Obiecując Berlinowi cesję Gdańska w zamian za podpisanie traktatu handlowego, liczyli na to, że dwór pruski zdecyduje się na podtrzymanie zwiąku z Rzeczapospolita. Dnia 6 września $1790 \mathrm{r}$. sejm podjął jednak uchwałę zabraniająca odstępowania jakiegokolwiek terytorium należacego do państwa polsko-litewskiego lub jego zamiany na inne. Przekreślało to plany zawarcia traktatu handlowego $z$ Prusami i Wielka Brytania oraz rozwiewało nadzieje rządu berlińskiego na aneksję przynajmniej Gdańska i Torunia za zgoda samych Polaków. Jak się jednak miało okazać, uchwała o „niepodzielności terytorium Rzeczypospolitej” stanowiła jedynie przejściowy zgrzyt w stosunkach polsko-pruskich. Dopóki trwał bowiem konflikt trójprzymierza $z$ Rosją, sojusz z Polska był nadal użyteczny dla dworu berlińskiego. Również w Warszawie $z$ dano sobie sprawę $z$ tego, że należy zaktywizować własna politykę zagraniczną i szukać oparcia w państwach wrogich dworowi petersburskiemu. Jesienią 1790 r. nastąpiło więc znaczne ożywienie działań dyplomacji polskiej. Przedstawiciele Rzeczypospolitej w Sztokholmie i Stambule prowadzili negocjacje w sprawie zawarcia

8 Por. M. Kucharski, op. cit., s. 87-93; J. Michalski, Dyplomacja polska..., s. 642; S. Askenazy, op. cit., s. 91-95; W. Konopczyński, op. cit., s. 235; Z. Anusik, Stosunki polsko-pruskie..., s. 215-216; idem, Dyplomacja szwedzka wobec kryzysu monarchii we Francji w latach 1787-1792, Łódź 2000, s. 287; id e m, Rzeczpospolita wobec wojny..., s. 160-161. 
sojuszów ze Szwecją i Turcją, rozpoczęte już wcześniej, bez porozumienia $z$ pruskim sojusznikiem ${ }^{9}$.

Niestety, wspomniane rokowania zakończyły się fiaskiem i nie doprowadziły do zawarcia formalnego układu $z$ jakimkolwiek nowym partnerem. W tej sytuacji, w poczatkach $1791 \mathrm{r}$. jedynym sojusznikiem Rzeczypospolitej pozostawały Prusy. Niemniej jednak, przywódcy sejmowi mieli dość dobre rozeznanie w zmieniającej się sytuacji na arenie międzynarodowej. Kiedy w końcu kwietnia Berlin oświadczył, że nie jest zainteresowany udziałem Rzeczypospolitej w planowanej wojnie przeciwko Rosji i zalecił Polakom zachowanie neutralności, w Warszawie natychmiast zrozumiano, że sojusz z Prusami zaczyna chwiać się w posadach. Zdając sobie sprawę $z$ wygasania pomyślnej dla Rzeczypospolitej koniunktury w stosunkach międzynarodowych, przywódcy Sejmu Wielkiego dokonali zamachu stanu, uchwalając 3 maja wiekopomną Ustawę Rządową. Jest również sprawą oczywistą, że wieści o wypadkach warszawskich zostały bardzo źle przyjęte w Berlinie. Nie dziwi też to, że król pruski i jego ministrowie unikali jakichkolwiek pisemnych deklaracji w tej kwestii. Pruski rząd nie zamierzał przecież przykładać ręki do sprawy polskich reform, którą od początku uważano za sprzeczna $z$ racją stanu państwa Hohenzollernów. Jest to problem znany od dawna i niepodlegajacy dyskusji. Co wydaje się jednak ważniejsze, o negatywnym nastawieniu pruskiego ministerium do Ustawy majowej $z$ pewnością wiedzieli również sternicy polskiej polityki zagranicznej. Wskazuja na to działania, jakie podjęto w Warszawie w krótkim czasie po uchwaleniu Ustawy Rządowej ${ }^{10}$.

${ }^{9}$ Por. S. Askenazy, op. cit., s. 97-103; M. Kucharski, op. cit., s. 93-95; J. Michalski, Dyplomacja polska..., s. 642-643; J. Łojek, Geneza i obalenie Konstytucji 3 maja. Polityka zagraniczna Rzeczypospolitej 1787-1792, Lublin 1986, s. 60-63; Z. Anusik, Stosunki polsko-pruskie..., s. 216-217; id e m, Misja polska..., s. 90-93; idem, Rzeczpospolita wobec wojny..., s. 161-163; Ostatni posel polski do Porty Ottomańskiej. Akta legacji stambulskiej Franciszka Piotra Potockiego, wyd. K. Waliszewski, t. I, Paris 1894, s. 170-171.

${ }_{10}$ Por. Z. Anusik, Rokowania o polsko-szwedzki traktat sojuszniczy w 1790 roku, „Zapiski Historyczne” 1996, t. LXI, z. 2-3, s. 21-44; id e m, Wznowienie stosunków..., s. 67-95; i d e m, Misja polska..., s. 90-94, 102-103; i d e m, O szwedzki alians. Karta $z$ dziejów stosunków politycznych pomiędzy Sztokholmem a Warszawa $w$ dobie Sejmu Czteroletniego, "Acta Universitatis Lodziensis”, Folia Historica 57, 1996, s. 77-106; id e m, Stosunki polsko-pruskie..., s. 219-220, 223-224; id e m, Czy dwór berliński proponował Szwecji udział $w$ drugim rozbiorze Polski? Przyczynek do dziejów stosunków politycznych pomiędzy Sztokholmem, Berlinem i Warszawa w latach 1789-1792, [w:] Oświeceni wobec rozbiorów Polski, red. J. Grobis, Łódź 1998, s. 43-63; i d e m, O polska koronę. Dwór sztokholmski wobec 
Uchwalenie Konstytucji 3 maja oznaczało istotny przełom w organizacji polskiej służby zagranicznej. Wraz z powołaniem Straży Praw $z$ królem na czele i powierzeniem urzędu ministra spraw zagranicznych podkanclerzemu litewskiemu Joachimowi Chreptowiczowi rozwiazana została Deputacja Interesów Zagranicznych. W ten sposób kierownictwo dyplomacji polskiej oraz polityki zagranicznej państwa wróciło do rąk Stanisława Augusta. W przeciagu dwóch tygodni od uchwalenia Ustawy Rządowej zapadły więc w stolicy Rzeczypospolitej brzemienne w skutki decyzje w sprawach dotyczących zarówno kierownictwa polskiej służby dyplomatycznej, jak i całokształtu polityki zagranicznej państwa. Warto może zastanowić się nad odpowiedzią na pytanie, jak mogło dojść w tak krótkim czasie do tak radykalnego przegrupowania sił politycznych, w wyniku którego odsunięto (na razie tylko formalnie) od wpływu na sprawy polityki zagranicznej państwa przywódców stronnictwa patriotycznego $z$ Ignacym Potockim i Stanisławem Małachowskim na czele? Odpowiedź na tak sformułowane pytanie wydaje się oczywista. Otóż już w połowie maja $1791 \mathrm{r}$. zdano sobie w Warszawie sprawę z ostatecznego załamania się akcji dworów londyńskiego i berlińskiego skierowanej przeciwko Rosji. Oznaczać to musiało definitywny rozkład podpisanego w marcu 1790 r. przymierza polsko-pruskiego. Wydaje się rzecza niemal pewną, że Stanisław August i przywódcy sejmowi uświadomili sobie całą doniosłość następstw załamania się planów wojny koalicji angielsko-pruskiej $z$ dworem petersburskim o miesiąc wcześniej, niż podjęto w Berlinie decyzje przesądzające w zasadzie o faktycznym zerwaniu przymierza $z$ Rzeczapospolitą ${ }^{11}$.

kwestii sukcesji tronu $w$ Polsce $w$ dobie Sejmu Czteroletniego, [w:] Studia i materiały $z$ dziejów nowożytnych, red. K. Matwijowski, S. Ochmann-Staniszewska, Prace historyczne XIII, Wrocław 1995, s. 147-167; idem, Szwedzki rywal Fryderyka Augusta. Gustaw III wobec projektów sukcesji tronu w Polsce w latach 1790-1792, „Rocznik Łódzki” 1997, t. XLIV, s. 89-115; id e m, Rzeczpospolita wobec wojny..., s. 163-169; M. Ku charski, op. cit., s. 106; W. Smoleński, Ostatni rok Sejmu Wielkiego, wyd. 2, Kraków 1897, s. 235-236.

11 Już w połowie maja 1791 r. Stanisław August był przekonany o małym prawdopodobieństwie rozpoczęcia wojny prusko-rosyjskiej. Pisał bowiem w tym czasie do Franciszka Bukatego znajdującego się w Londynie: „Lubo trwaja jeszcze wzajemne armowania się pruskie i moskiewskie, jednak powszechne jest mniemanie o zbliżajacym się pokoju”. Por. Stanisław August do F. Bukatego, Warszawa 14 V 1791, W. Kalinka, Ostatnie lata panowania Stanisława Augusta, wyd. 2, cz. 2 (Dokumenta do historyi drugiego i trzeciego podziału), Kraków 1891, s. 196. Trudno nawet przypuszczać, żeby przywódcy sejmowi, którzy doskonale odczytali doniosłość porozumienia prusko-austriackiego w Reichenbachu i jego wpływ na literę traktatu polsko-pruskiego $z$ marca 1790 r., nie uświadomili sobie wszystkich 
Bardzo istotne znaczenie dla kierunku przyszłej polityki zagranicznej państwa polsko-litewskiego miało obsadzenie stanowisk w Straży Praw. W pierwszych dniach po uchwaleniu Ustawy Rzadowej wydawało się zreszta, że kierownictwo resortu spraw zagranicznych znajdzie się $\mathrm{w}$ ręku jednego $z$ przywódców sejmowych. Protestując przeciwko wypadkom z 3 i 5 maja, Jacek Małachowski złożył bowiem urząd kanclerza wielkiego koronnego. Do pieczęci po Małachowskim kandydował poczatkowo Adam Kazimierz ks. Czartoryski. Kilka dni później Stanisław August poważnie rozważał z kolei możliwość powierzenia urzędu kanclerza wielkiego koronnego Ignacemu Potockiemu. Przewidywany w Warszawie rozwój wypadków na arenie międzynarodowej skłonił jednak przywódców stronnictwa patriotycznego do wycofania własnych kandydatur do pieczęci wielkiej koronnej i podjęcia (wraz z królem) działań zmierzających do nakłonienia Małachowskiego do powrotu do Warszawy oraz przyjęcia nominacji do Straży. Należy w tym miejscu zwrócić uwagę na to, że początkowo Stanisław August zamierzał powołać do Straży Praw aż czterech przedstawicieli stronnictwa patriotycznego (biskupa kujawskiego Józefa Ignacego Rybińskiego, Ignacego Potockiego, Stanisława Sołtana oraz Tomasza Ostrowskiego) i jednego tylko przeciwnika Ustawy Rządowej (Franciszka Ksawerego Branickiego). Dopiero w wyniku uzgodnień z przywódcami sejmowymi król zmienił swój pierwotny zamiar i zaakceptował skład Straży zasugerowany mu przez Hugona Kołłątaja. Ostatecznie w skład tej magistratury weszli: biskup krakowski Feliks Turski, który zastępować miał prymasa Michała Jerzego Poniatowskiego, kanclerz wielki koronny Jacek Małachowski, podkanclerzy litewski Joachima Chreptowicz, marszałek wielki litewski Ignacy Potocki, hetman wielki koronny Franciszek Ksawery Branicki i podskarbi nadworny koronny Tomasz Ostrowski. Do Straży Praw wszedł również z urzędu marszałek sejmu Stanisław Małachowski, na wniosek którego dokooptowano również do tego gremium marszałka konfederacji litewskiej - Kazimierza Nestora Sapiehę. W gronie najbliższych

następstw związanych $z$ załamaniem się planów wojny trójprzymierza $z$ dworem petersburskim. W tym miejscu warto przytoczyć również wypowiedź S. Askenazego, który pisząc o następstwach załamania się planów wojny Anglii i Prus z Rosja dla przymierza polsko-pruskiego, doszedł do wniosku, że: „Od czerwca 1791 r., przymierze $z$ Rzplita polską $z$ marca 1790 r. uważać można za nieistniejące dla króla i rządu pruskiego, za porzucone, za zerwane w zasadzie przez Prusy, zanim zostanie zerwane przez nie faktycznie i zamienione na przymierze przeciw Rzplitej polskiej”. Por. id e m, op. cit., s. 159. 
współpracowników króla znalazło się więc trzech zdeklarowanych stronników Rosji - Joachim Chreptowicz, Jacek Małachowski i Franciszek Ksawery Branicki. Nie było to bynajmniej dziełem przypadku. Skład Straży przekonać miał bowiem dwór petersburski o gotowości Warszawy do odejścia od dotychczasowej linii politycznej na rzecz ponownego zbliżenia $z$ Rosja. Wprowadzenie do Straży Praw czołowych malkontentów (obok niewątpliwego wydźwięku natury propagandowej, zarówno w kraju, jak i poza jego granicami) spowodować miało (w myśl koncepcji króla i pozostającego ówcześnie w bliskich $z$ nim stosunkach Hugona Kołłątaja) dezorientacje wśród przeciwników Ustawy Rządowej, neutralizację przywódców ewentualnych wystapień antykonstytucyjnych i roztoczenie nad nimi swoistej kurateli. Dodać też wypada, że przywódcy sejmowi byli przekonani o tym, że obecność w Straży Ignacego Potockiego i Stanisława Małachowskiego pozwoli im zachować kontrolę tak nad polityką wewnętrzna, jak i zagraniczną państwa ${ }^{12}$.

Nie wchodząc w dalsze szczegóły, należy raz jeszcze wyraźnie stwierdzić, że uzgodniona przez króla i przywódców sejmowych obsada stanowisk w Straży Praw wiodła wprost do radykalnego przegrupowania sił politycznych w Warszawie. W jego wyniku, przywódcy sejmowi, z Ignacym Potockim i Stanisławem Małachowskim na czele, zrezygnowali (przynajmniej pod względem formalnym) $z$ wywierania bezpośredniego wpływu na sprawy polityki zagranicznej państwa. Była to bez watpienia decyzja świadoma i dobrze przemyślana. W połowie maja $1791 \mathrm{r}$. przywódcy stronnictwa patriotycznego doszli bowiem do wniosku, że jeśli nie dojdzie do wybu-

12 Por. Stanisław August do F. Bukatego, Warszawa 7 i 14 V 1791, W. Kalinka, Ostatnie lata..., cz. 2, s. 193, 196; Stanisław August do Augustyna Debolego, Warszawa 7 V 1791, Rok nadziei, rok klesski. Z korespondencji Stanisława Augusta $z$ posłem polskim $w$ Petersburgu Augustynem Deboli, wyd. J. Łojek, Warszawa 1974, s. 50; Stanisław August do Maurice'a Glayre'a, Warszawa 21 VI 1791, Stanislas Poniatowski et Maurice Glayre. Correspondance relative aux partages de la Pologne, wyd. E. Mottaz, Paris 1897, s. 265; M. Wolski, Obrona Stanisława Augusta, wyd. B. Zaleski, „Rocznik Towarzystwa Historyczno-Literackiego w Paryżu”, R. 1867, Poznań 1867, s. 112; J. Wojakowski, Straż Praw, Warszawa 1982, s. 99-100, 108-109; J. Łojek, op. cit., s. 163-164; E. Rostworowski, Ostatni król Rzeczypospolitej. Geneza i upadek Konstytucji 3 maja, Warszawa 1966, s. 229-230; Z. Anusik, Kontrowersje wokół składu personalnego Straży Praw. Wpływ uwarunkowan międzynarodowych na sytuacje wewnętrzna $w$ Rzeczypospolitej $w$ ostatniej fazie obrad Sejmu Czteroletniego, [w:] 200 lat Konstytucji 3 Maja. Materiały z konferencji naukowej, red. M. Pawlak, Bydgoszcz 1992, s. $98-100$. 
chu otwartego konfliktu między trójprzymierzem a Katarzyną II, sojusz z Rzeczapospolita stanie się dla Prus zupełnie bezwartościowy. Ludzie kierujący do tej pory polityka zagraniczna państwa polsko-litewskiego uznali więc, że nadrzędnym celem polityki polskiej będzie w takim przypadku szukanie porozumienia $z$ dworem petersburskim. W tej kwestii występowała też zasadnicza zbieżność poglądów pomiędzy królem a przywódcami sejmowymi. W połowie maja 1791 r. zatem politycy wywierajaccy największy wpływ na tok obrad Sejmu Wielkiego podjęli decyzję o oddaniu w ręce Stanisława Augusta steru polityki zagranicznej państwa, obarczając go trudnym zadaniem odbudowania relacji $z$ dworem petersburskim ${ }^{13}$.

Skoncentrowanie w rękach króla wszystkich instrumentów polityki zagranicznej Rzeczypospolitej nie pociagnęło jednak za sobą zasadniczych zmian ani $\mathrm{w}$ zakresie reorientacji polityki na arenie międzynarodowej, ani też w dziedzinie organizacji polskiej służby dyplomatycznej poza granicami kraju. Specyficzny skład personalny Straży Praw posłużył natomiast Stanisławowi Augustowi jako pretekst do kompletnego sparaliżowania działalności tego organu. W konsekwencji Straż Praw, która w intencji ustawodawcy została pomyślana jako rada przyboczna króla, zajmowała się na swoich posiedzeniach sprawami zupełnie nieistotnymi $z$ punktu widzenia tak polityki zagranicznej, jak i wewnętrznej państwa ${ }^{14}$. Jak trafnie zauważył bowiem przed laty Bogusław Leśnodorski: „Straż Praw nie jest gabinetem, nie jest nim ani w pomyśle, ani w ostatecznym ułożeniu prawnym, mogła się dopiero przemienić w gabinet ministrów w toku ewolucji. Jest ona "radą królewską", monarcha zasadniczo sam decyduje. Nie ma "prezesa rady ministrów", nie ma pierwszego ministra, premiera, który umiałby nadawać rządowi ogólny ton i charakter. Nie ma jednolitej polityki "gabinetowej". Decyzje królewskie może podpisywać którykolwiek z ministrów niezależnie od swego resortu; nie podpisze jeden, może podpisać drugi, bardziej

${ }^{13}$ Por. Z. Anusik, Organizacja i funkcjonowanie..., s. 72-74; idem, Kontrowersje wokół składu..., s. 96-100; id e m, Stosunki polsko-pruskie..., s. 224-225; id e m, Rzeczpospolita wobec wojny..., s. 169-170; W. S moleń s ki, op. cit., s. 40; S. To m kow i c z, Z wieku Stanisława Augusta, Kraków 1882, s. 101.

14 Por. J. Łojek, op. cit., s. 160-163, 170; J. Wojakowski, op. cit., s. 96-97, 205-206 (tu zupełnie chybiona konstatacja, że Straż Praw pełniła funkcję koalicyjnego rządu, do którego weszli reprezentanci najsilniejszych stronnictw w Rzeczypospolitej); Z. Anu sik, Kontrowersje wokół składu..., s. 100-101. 
monarsze uległy i mniej bojący się odpowiedzialności"15. Umocniwszy swoją pozycję w strukturach władzy wykonawczej, zredukowawszy do minimum znaczenie Straży Praw i przejąwszy pełną kontrolę nad polityką zagraniczną Rzeczypospolitej, Stanisław August stopniowo emancypował się spod wpływu przywódców sejmowych.

Odsunięcie przywódców stronnictwa patriotycznego od istotnego wpływu na sprawy polityki zagranicznej państwa nie oznaczało jednak bynajmniej rozejścia się dróg króla i czołowych osobistości obozu konstytucyjnego. Pełna zgodność poglądów Stanisława Augusta i przywódców sejmowych ujawniła się bowiem np. w tak istotnej kwestii politycznej, jak kwestia stosunku do emigrantów, którzy intrygowali poza granicami kraju przeciwko Konstytucji 3 maja. Analiza środków przedsięwziętych przez władze Rzeczypospolitej w celu skłonienia malkontentów do powrotu do kraju i podporządkowania się woli sejmujacych stanów dała Władysławowi Smoleńskiemu asumpt do następującego stwierdzenia: „Zgrzeszyły niezaradnościa władze wykonawcze, sejm zawinił miękkością, król zaś przedsiębranymi na własną rękę środkami raczej szkodził sprawie, niż jej pomagał. W korespondencyi i rozmowach $z$ malkontentami różnych rang, wypierając się pół-słówkami solidarności $z$ postawa, zajęta przez przywódców, i słodząc gorycz uchwał sejmowych, demaskował słabość rządu, który usiłował być groźnym. Postępowaniem, nieodpowiadającym godności "głowy narodu", potęgował w malkontentach lekceważenie władzy i upór. Zawinił wreszcie król rozmyślnem oszczędzaniem ludzi zuchwałych i niebezpiecznych, o których wiedział dokładnie z depesz Deboli'ego"16. Zgadzając się, ogólnie rzecz biorąc, $z$ przytoczoną argumentacją, należy jednak wyraźnie podkreślić, że stanowisko królewskie popierane było w sejmie m.in. przez Stanisława Małachowskiego, Ignacego i Stanisława Kostkę Potockich oraz Tomasza Ostrowskiego, czyli ludzi, których patriotyzmu i przywiazania do zasad ustrojowych 3 maja nikt nigdy nie kwestionował.

Tymczasem zaś sytuacja zmieniała się nieubłaganie na niekorzyść państwa polsko-litewskiego. Latem 1791 r. rozpadła się bowiem koalicja angielsko-pruska. Dnia 26 lipca sprzymierzone dwory uznały bowiem wszystkie pretensje Rosji i zgodziły się na dokonanie przez nia aneksji ziem tureckich w rozmiarach, jakich

${ }^{15}$ B. Leśs nod ors ki, Dzieło Sejmu Czteroletniego (1788-1792). Studium historyczno-prawne, Wrocław 1951, s. 318-319.

16 W. Smoleński, op. cit., s. 421. 
domagała się cesarzowa. Kapitulacja Londynu i Berlina wobec dworu petersburskiego oznaczała de facto koniec trójprzymierza. Od tej pory, $z$ punktu widzenia Prus, sojusz z Rzeczapospolita przestał mieć jakiekolwiek znaczenie. Uwagę Wiednia i Berlina w coraz większym stopniu przyciagały natomiast wydarzenia $\mathrm{w}$ rewolucyjnej Francji. W dniu 23 czerwca 1791 r. zatrzymano bowiem w Varennes uciekająca $z$ Paryża rodzinę królewska. Tron Ludwika XVI mocno zachwiał się w posadach. Przyspieszyło to finalizację rokowań sojuszniczych między Austrią i Prusami. Dnia 25 lipca podpisano w Wiedniu traktat preliminaryjny, 4 sierpnia Austria zawarła pokój z Turcją w Szystowej, natomiast 27 sierpnia 1791 r. cesarz i król pruski ogłosili słynną deklarację w Pillnitz, wyrażającą ich wspólne zainteresowanie dla spraw rewolucji francuskiej. Warto w tym miejscu odnotować, że w tekście preliminarzy wiedeńskich z 25 lipca znalazł się punkt poświęcony Rzeczypospolitej. Oba dwory niemieckie deklarowały, że nie uczynia niczego, co mogłoby naruszyć jej granice i zagrozić utrzymaniu jej nowej konstytucji. Nie będa się też starać o narzucenie własnego kandydata na męża córki elektora saskiego Marii Augusty Nepomuceny (nazywanej polską infantka), która miała w przyszłości zasiąść na polskim tronie, a do świeżo zawartego porozumienia zaproszą w przyszłości dwór rosyjski. Miesiąc później, na zjeździe w Pillnitz potwierdzono w całości ten artykuł. Zbliżenie prusko-austriackie zostało bardzo dobrze przyjęte w Warszawie, gdzie uznano je za wydarzenie korzystne $z$ punktu widzenia bezpieczeństwa Rzeczypospolitej. W sierpniu 1791 r. do stolicy państwa polsko-litewskiego napłynęły jednak również mniej pomyślne wiadomości. Dnia 11 sierpnia podpisano bowiem w Gałaczu preliminarze pokoju rosyjsko-tureckiego. Działania wojenne na Bałkanach zostały przerwane, a Katarzyna II mogła zaczaćc myśleć o innym zatrudnieniu dla swoich żołnierzy. W dniu 19 października 1791 r. Rosja sprzymierzyła się zaś w Drottningholmie ze Szwecją. I chociaż sojusz ten skierowany był zasadniczo przeciwko rewolucyjnej Francji, to nie zmienia to faktu, że król Szwecji Gustaw III, nie tak dawno przecież rozważający pomysł zawarcia antyrosyjskiego sojuszu z Polska, stawał się sojusznikiem władczyni Rosji. $Z$ punktu widzenia Rzeczypospolitej, latem i jesienia 1791 r. na arenie międzynarodowej zaszły więc bardzo niepokojące zmiany ${ }^{17}$.

17 Por. S. Askenazy, op. cit., s. 166-173, 179-180; W. Smoleński, op. cit., s. 240-241; Z. Anusik, Szwedzki rywal..., s. 111; ide m, Dyplomacja szwedzka..., s. 354-408, 441-442; ide m, Rzeczpospolita wobec wojny..., s. 170; Curt 
W pierwszych miesiaccach 1792 r. nastapiła zaś seria wydarzeń, które stanowiły prawdziwe zagrożenie dla państwa polsko-litewskiego. Dnia 9 stycznia zawarto w Jassach (na bazie układów preliminaryjnych z Gałacza) pokój kończący wojnę rosyjsko-turecką. Oznaczało to radykalna zmianę sytuacji politycznej w Europie Środkowo-Wschodniej. Katarzyna II odzyskiwała pełna swobodę ruchów i w najważniejszych stolicach europejskich przypuszczano, że może ona podjać przygotowania do interwencji w Polsce. Na domiar złego, w obliczu zaostrzajacych się stosunków z Francjac, dwór wiedeński musiał pójść na niekorzystne dla Rzeczypospolitej ustepstwa wobec Berlina. Co prawda, 7 lutego 1792 r. podpisano traktat sojuszniczy między Austria i Prusami, w którym gwarantowano całość Rzeczypospolitej, ale nie było tu już mowy o pruskiej gwarancji dla Ustawy Rządowej. Jak by tego było mało, 1 marca zmarł cesarz Leopold II, a 20 kwietnia Francja wypowiedziała wojnę jego następcy. W tym momencie stało się jasne, że Austria, która jako jedyne $z$ mocarstw rozbiorowych gotowa była zaakceptować polska konstytucję, nie będzie w stanie udzielić Rzeczypospolitej żadnej realnej pomocy politycznej, nie wspominając już o pomocy wojskowej. Niemal w tym samym czasie doszło też do przesilenia politycznego w Sztokholmie. Dnia 16 marca dokonano zamachu na życie Gustawa III, a 29 marca 1792 r. król zmarł w wyniku zakażenia rany postrzałowej. W ten sposób wyeliminowany został z rozgrywki politycznej władca, którego nieobliczalne i trudne do przewidzenia poczynania mogłyby znacznie utrudnić wprowadzenie w życie wrogich wobec Rzeczypospolitej pomysłów dojrzewajacych właśnie na dworze petersburskim ${ }^{18}$.

W tym miejscu wypada przedstawić stanowisko Rosji wobec wydarzeń rozgrywajacych się w Rzeczypospolitej w okresie po uchwaleniu Konstytucji 3 maja. Rzecz jasna, Katarzyna II była zdecydowanie

von Stedingk do Gustawa III, Petersburg 24 X/4 XI 1791, Riksarkivet w Sztokholmie [dalej: RA], Muscovitica vol. 451, karty bez paginacji (uwaga ta dotyczy także wszystkich innych, przywoływanych niżej zbiorów Riksarkivet).

18 Por. W. Kalinka, Polityka dworu austryackiego $w$ sprawie konstytucyi 3 maja, Kraków 1873, s. 41-43; S. Askenazy, op. cit., s. 186-190; W. S moleńs ki, op. cit., s. 236-238, 254-255; B. D e m biń s ki, Rosya a rewolucya francuska, Kraków 1896, s. 21-22, 94, 139, 158-159, 165, 206-207, 211, 213; J. Łojek, Misja Debolego w Petersburgu w latach 1787-1792. Z dziejów stosunków polsko-rosyjskich $w$ czasach Sejmu Czteroletniego, Wrocław 1962, s. 122-124; Z. Anusik, Misja polska..., s. 120-121; idem, Szwedzki rywal..., s. 114-115; idem, O polska korone..., s. 165-166; idem, Rzeczpospolita wobec wojny..., s. $170-171$. 
przeciwna reformatorskim poczynaniom Sejmu Wielkiego. $Z$ niezadowoleniem przyjęła też wieści o uchwaleniu Ustawy Rządowej. Ponieważ jednak w maju 1791 r. groził jej wybuch wojny $z$ koalicją angielsko-pruską, na razie postanowiła grać na zwłokę. Możliwe warianty postępowania wobec Rzeczypospolitej przedstawiła w datowanym na 16/27 maja reskrypcie dla naczelnego wodza armii rosyjskiej walczącej z Turcja - księcia Grigorija A. Potiomkina. W pierwszym dopuszczała możliwość zapewnienia Polaków, że Rosja nie zamierza mieszać się do spraw wewnętrznych Rzeczypospolitej, gotowa jest zawrzeć przymierze gwarantujace całość jej granic, jak również korzystny dla Polski układ handlowy. Co więcej, dołoży starań, aby Rzeczpospolita mogła uzyskać Mołdawię, jak również zgodzi się na objęcie tronu polskiego przez elektora saskiego, jeśli ten zapewni, że panujac $\mathrm{w}$ Polsce nie naruszy pokoju $z$ sąsiadami. $Z$ tego typu działaniami zalecała jednak wstrzymać się do czasu, aż do Petersburga nadejdą bardziej szczegółowe informacje o przebiegu polskiej rewolucji, jak również o stanowisku dworu wiedeńskiego. W drugim, zalecała podjęcie kroków zmierzających do zawiązania w Polsce rekonfederacji przeciwników nowej konstytucji. Ewentualnym przywódcom obiecywała opiekę i poparcie ze strony Rosji. Trzeci wariant przewidywał (zgodnie $z$ wcześniejszymi sugestiami Potiomkina), wprowadzenie wojsk rosyjskich do województw kijowskiego, bracławskiego i podolskiego. W ostateczności cesarzowa gotowa była wyrazić zgodę na dokonanie zaboru ziem polskich przez Prusy, pod warunkiem, że i Rosja otrzyma swoją część. Na razie były to jednak rozważania o czysto teoretycznym charakterze. Co w tym wszystkim wydaje się bowiem najważniejsze to fakt, że cesarzowa zezwalała księciu Taurydy na podjęcie wrogich działań przeciwko Rzeczypospolitej jedynie w przypadku pojawienia się w jej granicach wojsk pruskich. Ponieważ w owym czasie było to bardzo mało prawdopodobne, należy uznać, że w istocie Katarzyna II starała się powstrzymać Potiomkina od podejmowania jakichkolwiek działań skierowanych przeciwko państwu polsko-litewskiemu. W Petersburgu zdecydowano się bowiem czekać na dalszy rozwój wypadków ${ }^{19}$.

19 Por. Katarzyna II do ks. Grzegorza A. Potemkina Tauryckiego, Carskie Sioło 16/27 V 1791 (reskrypt), W. Kalinka, Ostatnie lata..., cz. 2, s. 120-123. Warto przytoczyć w tym miejscu interpretację tego reskryptu dokonana przez Szymona Askenazego: „Wyglądało to więc pozornie na udzielenie carte blanche księciu Tauryckiemu. Ale to wszystko postawione było w zależności od jednego kardynalnego warunku: polsko-pruskiej zaczepki, zbrojnej napaści na Rosyę. Reskrypt zaczynał się od słów: "Anglia gotuje się wysłać flotę na morze Bałtyckie, Śródziemne, Czarne", 
Potiomkin nie miał zresztą na razie okazji zrobić czegokolwiek w sprawie polskiej, gdyż w chwili sporządzenia przeznaczonego dla niego reskryptu przebywał w Petersburgu. W stolicy Rosji pozostać miał też przez kilka następnych miesięcy. Jego zachowanie, zdradzające objawy postępującej choroby psychicznej, budziło coraz większy niepokój tak cesarzowej, jak i jej faworyta - Płatona A. Zubowa. Potiomkin był jednak zbyt potężny, aby można go było tak po prostu odsunąć od wpływu na sprawy państwa. Książę Taurydy był bowiem nie tylko naczelnym wodzem armii wojujacej z Turcja, lecz także politykiem, który mógł odegrać istotna rolę w procesie przywracania wpływów rosyjskich w Rzeczypospolitej. Już w początkach 1791 r. Potiomkin, który od dawna snuł plany utworzenia w Polsce rekonfederacji i dokonania aneksji województw ukrainnych, nawiązał kontakt $z$ jednym $z$ czołowych (obok Seweryna Rzewuskiego) przeciwników reform dokonywanych na Sejmie Wielkim, przebywającym ówcześnie na emigracji, generałem artylerii koronnej Stanisławem Szczęsnym Potockim. Na wieść o uchwaleniu Konstytucji 3 maja Potocki zwrócił się do księcia Taurydy z propozycja podjęcia wspólnych działań zmierzających do obalenia dzieła Sejmu Czteroletniego. Potiomkin przekazał list Potockiego Katarzynie II. Cesarzowa, która od dawna myślała o pozbyciu się księcia Taurydy z Petersburga, zdecydowała się upiec dwie pieczenie przy jednym ogniu. Dnia 18/29 lipca 1791 r. władczyni Rosji wręczyła Potiomkinowi dwa nowe, „najtajniejsze” reskrypty na jego imię. W pierwszym, zasadniczym dokumencie, zalecała mu natychmiastowy wyjazd do armii w celu zawarcia ostatecznego pokoju $z$ Turcją. Wiedząc, że książę jest zwolennikiem kontynuowania wojny z sułtanem, przygotowała mu bardzo szczegółowe instrukcje dotyczące warunków przyszłej pacyfikacji i sposobu prowadzenia negocjacji pokojowych. W drugim, dodatkowym reskrypcie była mowa o sprawach polskich. Katarzyna II zezwalała w nim Potiomkinowi na rozpoczęcie przygotowań do wystąpienia przeciwko Konstytucji 3 maja, najlepiej zaraz po zakończeniu wojny $z$ Turcją. Polecała księciu, aby udzielił pomo-

i od zapowiedzi marszu pruskiego na Rygę. Otóż, ten reskrypt był datowany 27 maja 1791 r. Kiedy kładła na nim podpis carowa, posiadała już pewność absolutna, że żaden angielski żagiel, żaden pruski batalion nie zagraża więcej Rosyi, że o zaczepce, o napaści niema już mowy, że wojny napewno nie będzie. Stawiając świadomie Potemkinowi warunek fikcyjny, czyniła fikcyjnem całe udzielone mu pełnomocnictwo". Por. idem, op. cit., s. 182. Por. też W. S moleński, op. cit., s. 172-173 (tu dosłowne odczytanie reskryptu majowego); oraz J. Łojek, Geneza i obalenie..., s. 176-177 (tu wsparcie interpretacji Askenazego). 
cy Potockiemu i Rzewuskiemu, którzy powinni zorganizować w Polsce liczne i silne stronnictwo antykonstytucyjne, a następnie zwrócić się o pomoc do Rosji. Cesarzowa pisała też o konieczności uzyskania zgody na tę akcję ze strony Leopolda II oraz wysondowania stanowiska dworu berlińskiego. Celem nadrzędnym proponowanych działań miało być przywrócenie w Polsce porządków sprzed $1788 \mathrm{r}$. W razie niemożności osiagnięcia tego celu cesarzowa dopuszczała możliwość dokonania nowego podziału ziem Rzeczypospolitej między jej trzech sąsiadów. W oczekiwaniu na ostateczne rozstrzygnięcia zalecała polskim malkontentom mnożenie antykonstytucyjnych manifestów i zawiązanie rekonfederacji jeszcze przed wkroczeniem wojsk rosyjskich w granice Rzeczypospolitej. Potiomkin miał też zapewnić przywódców planowanej antykonstytucyjnej konfederacji o poparciu ich działań przez oba dwory cesarskie, ale jednocześnie miał trzymać przed wszystkimi Polakami w największym sekrecie pomysły dokonania nowego rozbioru. Katarzyna II poradziła też księciu Taurydy, żeby wezwał Szczęsnego Potockiego do swojej kwatery głównej w Jassach w celu omówienia szczegółów planowanych działań. Podobnie jak w przypadku reskryptu majowego, cesarzowa obwarowała jednak swoja zgodę na rozpoczęcie akcji w Polsce kilkoma niemożliwymi do spełnienia warunkami, z których najważniejszym wydaje się pomysł wciągnięcia do wspólnej akcji przeciwko Rzeczypospolitej dworu wiedeńskiego. Oznaczało to ni mniej, ni więcej, tylko to, że dwór petersburski nie wypracował jeszcze ostatecznej koncepcji rozwiązania sprawy polskiej, a kolejny reskrypt dla księcia Taurydy był dokumentem bez istotnego znaczenia politycznego, nieujawniającym bynajmniej prawdziwych intencji Katarzyny II. Zaopatrzony w instrukcje, które prowadziły do odsunięcia w bliżej nieokreślona przyszłość realizacje jego wrogich zamysłów wobec Rzeczypospolitej, w poczatkach sierpnia $1791 \mathrm{r}$. Potiomkin wyjechał z Petersburga. Nawet jeśli nie oznaczało to jego definitywnej niełaski, było pewne, że Zubow i jego adherenci nie dopuszczą do tego, aby książę Taurydy zrealizował pomysły zawarte w piśmie cesarzowej. Nie może więc dziwić to, że jedynym posunięciem Potiomkina zgodnym $z$ treścia reskryptu lipcowego było zaproszenie do Jass przywódców polskich malkontentów. W początkach października 1791 r. Szczęsny Potocki i Seweryn Rzewuski opuścili też Wiedeń, udając się na spotkanie $z$ księciem Taurydy ${ }^{20}$.

${ }^{20}$ Por. E. Rostworowski, Potocki Stanisław Szczęsny, [w:] PSB, t. XXIX, Wrocław 1984-1985, s. 192-193; Katarzyna II do G.A. Potemkina Tauryckiego, 
Potocki przybył do Jass 15 października 1791 r. Nie zastał tu Potiomkina, który chory, wyjechał kilka godzin wcześniej w kierunku Mikołajewa. Następnego dnia przybył do Jass Rzewuski. Niemal jednocześnie nadeszła tu wieść o śmierci księcia Taurydy, który zmarł w stepie 5/16 października. Wiadomość o zgonie Potiomkina wywołała przerażenie i konsternację obu Polaków. Wraz ze smiercia księcia Taurydy cały, układany od kilku miesięcy plan zawiazania antykonstytucyjnej rekonfederacji w Polsce, wspartej następnie przez wojska imperatorowej, stracił bowiem swojego jedynego w tym momencie promotora. Na dworze rosyjskim zdecydowano się spokojnie czekać na dalszy rozwój wypadków. Opiekę nad obu malkontentami roztoczył tymczasowo szef sztabu Potiomkina, generał Wasyl S. Popow. On też przesłał do Petersburga listy Potockiego i Rzewuskiego adresowane bezpośrednio do imperatorowej. W oczekiwaniu na dalsze rozkazy władczyni Rosji obaj magnaci opuścili Jassy i przenieśli się najpierw do Jazłowca, a następnie do Galicji. Tymczasem na dworze petersburskim podjęto decyzję, żeby dalsze rozmowy $z$ polskimi malkontentami prowadził rzeczywisty tajny radca, faktyczny kierownik Kolegium Spraw Zagranicznych Aleksander A. Bezborodko, któremu po śmierci Potiomkina powierzono ukończenie pertraktacji o zawarcie definitywnego pokoju z Turkami. Bezborodko dotarł do Jass 2/13 listopada $1791 \mathrm{r}$. Od kilku dni przebywał tu już hetman wielki koronny Franciszek Ksawery Branicki, który przyjechał objać w imieniu żony (od dawna bawiącej u boku Potiomkina) spadek po księciu Taurydy. Dnia 19/30 listopada pojawili się w Jassach, wezwani przez Bezborodkę Szczęsny Potocki i Seweryn Rzewuski. Co warto podkreślić, Aleksander A. Bezborodko był rzecznikiem rozwiązania sprawy polskiej w porozumieniu z Austrią i Prusami. W pierwszej kolejności liczył się jednak $z$ opinią dworu wiedeńskiego, który od dawna deklarował poparcie dla Konstytucji 3 maja i był zdecydowanie przeciwny zbrojnej interwencji w Rzeczypospolitej. Nie dziwi więc to, że rozmowy Bezborodki z polskimi malkontentami nie zakończyły się wypracowaniem żadnego planu działania. Na przedstawiane mu przez Potockiego i Rzewuskiego projekty rosyjski dygnitarz odpowiadał ogólnikami i unikał podejmowania jakichkolwiek zobowiązań. W końcu, w styczniu 1792 r. zaproponował Katarzynie II, aby

Carskie Sioło 18/29 VII 1791 (reskrypt), W. Kalinka, Ostatnie lata.., cz. 2, s. 127-132; W. S moleń s ki, op. cit., s. 179-182; S. A s ke nazy, op. cit., s. 182-183; J. Łojek, Geneza i obalenie..., s. 177-178. 
zezwoliła obu malkontentom udać się do Petersburga, gdzie miano ostatecznie uzgodnić szczegóły działania w sprawie polskiej. Cesarzowa wyraziła zgodę na takie rozwiązanie. Jak się miało okazać, był to jednen $z$ największych błędów Bezborodki w całej jego politycznej karierze ${ }^{21}$.

W pierwszych miesiącach $1792 \mathrm{r}$. na dworze petersburskim ukształtował się nowy układ polityczny, w którym decydującą rolę odgrywać zaczął swoisty triumwirat złożony z Płatona A. Zubowa, Arkadija I. Morkowa i Wasyla S. Popowa. To właśnie $z$ tymi politykami (dzięki pośrednictwu Szymona Kossakowskiego) związali się też ostatecznie polscy malkontenci, którzy przybyli do Petersburga w połowie marca 1792 r. Należy zaznaczyć, że początkowo wpływowe koła dworskie w Petersburgu dość sceptycznie odnosiły się do pomysłu zbrojnej interwencji w Rzeczypospolitej. Jeszcze więcej zastrzeżeń miał Aleksander A. Bezborodko, który powrócił do stolicy Rosji 21 marca 1792 r. Okazało się bowiem, że w czasie jego nieobecności kierownictwo spraw zagranicznych zagarną całkowicie Arkadij I. Morkow, a kierownikiem całej polityki państwa stał się faktycznie Płaton A. Zubow. W rękach kliki Zubowa, która przejęła na własny użytek wszystkie pomysły lansowane dawniej przez Grigorija A. ks. Potiomkina i od początku dążyła do dokonania zaboru ziem Rzeczypospolitej, sprawa polska stała się też narzędziem zupełnego pognębienia politycznych przeciwników na dworze imperatorowej. W ten sposób wytworzyła się sytuacja, w której Bezborodko, rozwścieczony faktem, że odsunięto go od kierowania polityką zagraniczną państwa i poczyniono już daleko idące obietnice polskim malkontentom, postanowił (ze swoimi politycznymi przyjaciółmi) wystapić przeciwko planom Zubowa i Morkowa, zdając sobie sprawę $z$ tego, że ich realizacja przesądzi na długo o preponderancji potężnego faworyta ${ }^{22}$.

${ }^{21}$ Por. Z. Zielińska, Rzewuski Seweryn, [w:] PSB, t. XXXIV, Wrocław-Warszawa-Kraków 1992-1993, s. 146; E. Rostworowski, Potocki Stanisław..., s. 193-194; W. S moleń ski, op. cit., s. 187-188, 191-196, 303; J. Łojek, Geneza i obalenie..., s. 172, 224-225; Z. An u sik, Rzeczpospolita wobec wojny..., s. 174.

${ }^{22}$ Por. W. Smoleński, op. cit., s. 303-307; J. Łojek, Geneza i obalenie..., s. 224-225, 264-266; Z. Anusik, Rzeczpospolita wobec wojny..., s. 175-176. Odmienne spojrzenie na kwestie ówczesnej polityki dworu petersburskiego wobec Rzeczypospolitej prezentuja w swoich pracach m.in. E. Rostworowski, A. Zahorski i Z. Zielińska. Poglądy tych autorów wyraża następujące stwierdzenie J. Michalskiego: „Katarzyna II oswajała się coraz bardziej z rozbiorowym wariantem rozwiazania sprawy polskiej, podsuwanym jej przez większość doradców obawiających się, że próba powrotu do sytuacji $z$ lat 1775-1788 narazi wyczerpane państwo na 
Próbę zablokowania lub też opóźnienia realizacji planów zbrojnej interwencji w Rzeczypospolitej podjał Bezborodko ze swoimi adherentami na posiedzeniu Rady Państwa w dniu 29 marca/9 kwietnia 1792 r. Co prawda, zaakceptowano wówczas projekt deklaracji w sprawie polskiej oraz treść reskryptów dla dowodzących armiami stacjonującymi na granicach Rzeczypospolitej generałów Michaiła W. Kachowskiego i Michaiła N. Kreczetnikowa, ale jednocześnie członkowie Rady zażądali, aby przed rozpoczęciem działań wojennych zapoznać się ze stanowiskiem dworów wiedeńskiego i berlińskiego (w tym drugim przypadku obawiano się, żeby Prusy nie wypełniły swoich sojuszniczych zobowiazzan wobec Polski). Katarzyna II zaakceptowała decyzję Rady Państwa, co oznaczać musiało kolejna zwłokę w realizacji planów grupy skupionej wobec Płatona A. Zubowa. Kilkanaście dni później cesarzowa zmieniła jednak swoją wcześniejszą decyzję. Być może miało to związek $z$ otrzymaniem wiadomości o śmierci króla Szwecji Gustawa III. W każdym razie, 12/23 kwietnia wysłano rozkazy do Kachowskiego i Kreczetnikowa, aby byli gotowi do wkroczenia do Rzeczypospolitej w połowie maja 1792 r. Zdecydowano również o wysłaniu na ręce Jakowa Bułhakowa, posła rosyjskiego w Warszawie tekstu deklaracji dworu petersburskiego. Na poczynania imperatorowej wpływało też bez wątpienia nastawienie wpływowych kół dworskich. Przeciwko koncepcji pokojowego rozwiązania sprawy polskiej lansowanej przez Bezborodkę opowiedziała się bowiem ogromna liczba dworzan i oficerów, dążących do uzyskania od cesarzowej lukratywnych nadań na ziemiach odebranych Rzeczypospolitej. Dnia 27 kwietnia

nowe poważne konflikty międzynarodowe, przede wszystkim z Prusami. Przyłączenie województw ukraińskich, po złych doświadczeniach zamknięcia przez nie przejścia i po pozyskaniu terenów między Bohem a Dniestrem, stawało się coraz bardziej wymogiem racji stanu. Dalekosiężne jednak ambicje rozciagnięcia wpływów nad nieuszczuploną Rzeczpospolita i antypatia do Prus za ich politykę w latach 1788-1791 powodowały, że Katarzyna II nie była całkowicie zdecydowana na ów wariant. Natomiast likwidacja emancypacji Polski była dla niej sprawą przesadzona i uważana za pierwszoplanowe zadanie polityczne". Por. id e m, Dyplomacja polska..., s. 619-620. Ten sam autor twierdził również, że o ile klika Zubowa dażyła do interwencji w Polsce dokonanej bez porozumienia $z$ innymi dworami, o tyle Bezborodko chcial interwencji uzgodnionej z Prusami i od poczatku był rzecznikiem myśli rozbiorowej. Dodajmy jednak w tym miejscu, że nawet jeśli Bezborodko rzeczywiście początkowo popierał pomysł zbrojnej interwencji w Rzeczypospolitej i dokonania jej rozbioru w porozumieniu $z$ Berlinem (co oznaczało konieczność znacznego przesunięcia w czasie realizacji tych pomysłów), to stał się zdecydowanym przeciwnikiem tych planów w momencie, kiedy za ich realizację zabrał się Płaton A. Zubow $z$ grupa swoich popleczników. 
1792 r. polscy malkontenci zaprzysięgli i podpisali w Petersburgu akt konfederacji generalnej koronnej, którą datowano następnie, rzekomo w Targowicy, na 14 maja 1792 r., w terminie planowanego pierwotnie wkroczenia do Polski wojsk rosyjskich ${ }^{23}$.

Jeśli na dworze petersburskim zwlekano jeszcze $z$ wprowadzeniem do Rzeczypospolitej skoncentrowanych na jej granicach armii, to tylko $z$ powodu niepewności cesarzowej co do postawy dworów wiedeńskiego i berlińskiego. Już wkrótce jednak do Petersburga nadeszły bardzo pomyślne wieści. W dniu 9 maja 1792 r. kurier z Berlina przywiózł bowiem wiadomość, że 20 kwietnia francuskie Zgromadzenie Narodowe wypowiedziało wojnę następcy Leopolda II, królowi Węgier Franciszkowi. Wieść o wybuchu wojny francusko-austriackiej niezmiernie ucieszyła zwolenników rozprawy z Polską. Jeśli bowiem Katarzyna II miała jeszcze jakiekolwiek wątpliwości co do słuszności proponowanego jej rozwiąania, to teraz, w obliczu zaangażowania się obu sprzymierzonych dworów niemieckich na zachodzie Europy, $z$ latwościa uległa argumentom przedstawianych jej przez Płatona A. Zubowa i jego adherentów. Kilka dni później, 18 maja 1792 r. Jakow Bułhakow zadeklarował w Warszawie sprzeciw swojego dworu wobec Konstytucji 3 maja. Tego samego dnia wojska rosyjskie wkroczyły też w granice Rzeczypospolitej ${ }^{24}$.

Los państwa polsko-litewskiego nie był jeszcze bynajmniej przesądzony. Już po rozpoczęciu działań wojennych z kręgu polityków skupionych wokól osoby Aleksandra Bezborodki dały się słyszeć opinie, że interwencja zbrojna w Rzeczypospolitej jest poważnym błędem. Wicekanclerz Iwan A. Ostermann, przyjaciel i formalny zwierzchnik Bezborodki otwarcie mówił, że „Polacy nigdy nie mieli lepszej konstytucji, jak ta obecna, czego najlepszym dowodem jest ich jedność w tej kwestii, a konfederaci, którzy chca ją obalić, sa bandą ogarniętych wściekłością głupców". Warto również zwrócić uwage na to, że jeszcze w połowie lipca 1792 r., kiedy na dworze petersburskim zastanawiano się nad treścia odpowiedzi cesarzowej na list Stanisława Augusta z 22 czerwca, ponownie doszło do starcia koterii Aleksandra A. Bezborodki z klika Płatona A. Zubowa.

${ }^{23}$ Por. C. von Stedingk do Gustawa IV Adolfa, Petersburg 18/29 IV 1792, RA, Muscovitica vol. 452; Z. Anusik, Rzeczpospolita wobec wojny..., s. 177-178; i de m, Misja polska..., s. 128; C. von Stedingk do Samuela N. Casströma, Petersburg 21 V/1 VI 1792, RA, Polonica vol. 229; W. Smoleński, op. cit., s. 316-317; i de m, Konfederacja targowicka, Kraków 1903, s. 30-31.

${ }^{24}$ Por. Z. Anusik, Rzeczpospolita wobec wojny..., s. 178-179; W. Smoleński, Ostatni rok Sejmu..., s. 396-397. 
Katarzyna II, znużona przedłużającą się wojną i całą sprawą, pod wpływem rad Bezborodki i jego politycznych przyjaciół gotowa była przystać na zawieszenie broni i podjać rokowania $z$ dworem warszawskim. Jednak ponownie przeważyło zdanie Zubowa, Morkowa i Popowa. Faworyt przekonał bowiem carowa, że jej honor wymaga, aby podtrzymała swoje poparcie dla konfederacji targowickiej i nie zmieniała niczego w twardych warunkach, jakie wcześniej zamierzano narzucić polskiemu królowi ${ }^{25}$.

Podsumowując dotychczasowe wywody, należy jednoznacznie stwierdzić, że w przededniu podjęcia decyzji o interwencji w Polsce na dworze petersburskim istniały dwie, zwalczające się zaciekle koterie polityczne. Pierwsza z nich tworzyli Płaton A. Zubow, Arkadij I. Morkow i Wasyl S. Popow. Na czele drugiej stał Aleksander A. Bezborodko wspierany przez Iwana A. Ostermanna i Aleksandra R. Woroncowa. Grupa skupiona wokół faworyta cesarzowej ściśle współpracowała $z$ polskimi malkontentami i zmierzała do zbrojnej interwencji w Rzeczypospolitej oraz do zaboru części jej terytorium. Klika Zubowa nie wykluczała też możliwości dokonania rozbioru państwa polsko-litewskiego w przypadku, gdyby przeciwko jednostronnemu zaborowi zaprotestowały dwory niemieckie. Bezborodko i jego adherenci lansowali natomiast koncepcję pokojowego ułożenia stosunków z Polską, dopuszczając nawet do siebie myśl o utrzymaniu w Rzeczypospolitej przynajmniej części rozwiąań prawno-ustrojowych z czasów Sejmu Czteroletniego. Już w czasie trwania działań wojennych Bezborodko, dążąc do sparaliżowania akcji swoich politycznych przeciwników, gotów był zaakceptować wysunięta przez Polaków propozycję zawieszenia broni i wstrzymania marszu wojsk rosyjskich w kierunku Warszawy. Warto w tym miejscu zaznaczyć, że najważniejsi urzędnicy Kolegium Spraw Zagranicznych kierowali się w swoich działaniach przeświadczeniem, że możliwe jest uregulowanie stosunków $z$ Polską na drodze negocjacji. Uważali, że ewentualna interwencja zbrojna w Rzeczypospolitej powinna zostać uzgodniona $z$ dworami niemieckimi. Byli też przekonani o tym, że wkroczenie wojsk rosyjskich w granice państwa polsko-litewskiego doprowadzi do wybuchu wojny, która

25 Por. C. von. Stedingk do Karola ks. Sudermańskiego, Petersburg 12/23 V 1792, RA, Muscovitica vol. 452; Jerzy Michał Potocki do Stanisława Augusta, Sztokholm 20 i 27 VII 1792, Biblioteka Naukowa PAU i PAN w Krakowie [dalej: BPAU], rkps 1652, k. 208, 211; Z. Anusik, Rzeczpospolita wobec wojny..., s. 179-180; i d e m, Misja polska..., s. 129. 
będzie długotrwała i bardzo kosztowna. Sądzić wypada, że właśnie tych kosztów chcieli za wszelką cenę uniknąć. Płaton A. Zubow i jego poplecznicy, mamieni fantasmagoriami roztaczanymi przez polskich malkontentów, dążyli zaś do natychmiastowego uderzenia na Polskę, bez oglądania się na stanowisko Wiednia i Berlina. Wierzyli, że wojska rosyjskie nie napotkaja na poważniejszy opór i szybko zmuszą Polaków do kapitulacji. Zgodnie $z$ ich koncepcjami, przywróceniu rosyjskiej przewagi w Polsce towarzyszyć miał zabór jej wschodnich terytoriów. Zasadne wydaje się również stwierdzenie, że ingerencja w wewnętrzne sprawy Rzeczypospolitej dokonana $z$ inicjatywy i ze współudziałem drapieżnej kliki Zubowa przesądziła $\mathrm{w}$ istocie sprawę przyszłego rozbioru. Tylko dzięki jednostronnemu zaborowi lub też kolejnemu rozbiorowi Rzeczypospolitej dwór petersburski mógł bowiem zrekompensować sobie wydatki poniesione w czasie wojny tureckiej. Rozbiór pozwalał też spełnić marzenia stronników Zubowa o nowych pensjach, gratyfikacjach i nadaniach ziemskich. Dla nikogo nie powinien też stanowić zaskoczenia fakt, że kiedy doszło wreszcie do drugiego rozbioru Polski, Katarzyna II wykroiła sobie pars leonis z terytorium pokonanej i upokorzonej Rzeczypospolitejé ${ }^{26}$.

${ }^{26}$ Por. Z. Anusik, Między Warszawa, Sztokholmem i Petersburgiem. Gene$z a$ rosyjskiej interwencji $w$ Polsce $w 1792$ r. $w$ świetle korespondencji ambasadora szwedzkiego w Petersburgu Curta von Stedingka, [w:] Przełomy $w$ historii. XVI Powszechny Zjazd Historyków Polskich (Wrocław 15-18 września 1999 roku). Pamiętnik, t. II, cz. 1, Torun 2000, s. 274-275; id e m, Rzeczpospolita wobec woj$n y \ldots$, s. 182-183. Warto $\mathrm{w}$ tym miejscu przytoczyć również relację naocznego świadka wydarzeń rozgrywajacych się w Petersburgu wiosna 1792 r. Szwedzki ambasador w stolicy Rosji tak oto pisał bowiem do posła szwedzkiego w Warszawie już po wybuchu wojny polsko-rosyjskiej: „Nadeszła chwila, kiedy ta biedna Polska doświadcza nowego nieszczęścia ze strony rządu występnego i kierującego się niegodnym egoizmem, który poniża godność tego narodu. Nie wątpię, że jego nowa konstytucja jest rzeczywiście o wiele lepsza od poprzedniej, ale jest ona tego rodzaju, że nie podoba się sąsiadom Polski, zwłaszcza Rosji, która przywykła uważać Polskę za swego wasala. Jej Wysokość Cesarzowa nie chce bynajmniej nowego rozbioru Polski. Chce ona jedynie przywrócić tam ponownie swoją przewage i przeszkodzić utrwaleniu się oporowi (przeciwko jej dominacji) przez ustanowienie dziedzicznego tronu... Rada Jej Wysokości Cesarzowej Rosji była (do końca) podzielona na partie, spośród których Jej Wysokość musiała dokonać wyboru. Ministrowie bardziej doświadczeni byli zdania, że należy wybrać drogę porozumienia i negocjacji, młodsi i bardziej ambitni preferowali jednak przemoc i doradzali uderzenie zbrojne, który to sposób był im podsuwany przez polskich emigrantów... tylko szybkie poddanie się woli Imperatorowej albo też zaciekły opór będą w stanie (w obecnych okolicznościach) uratować Polskę". Por. C. von Stedingk do S.N. Casströma, Petersburg 21 V/ 1 VI 1792, RA, Polonica vol. 229. 
Jak więc widzimy, w okresie po uchwaleniu Konstytucji 3 maja istniały realne szanse na ułożenie na nowych zasadach stosunków Rzeczypospolitej z Rosją. Decyzja przywódców Sejmu Wielkiego o przekazaniu Stanisławowi Augustowi sterów polityki zagranicznej państwa była $z$ pewnością słuszna i oparta na racjonalnych przesłankach. Pozostaje zatem pytanie o to, jak król skorzystał z przyznanych mu prerogatyw. Otóż wypada w tym miejscu stwierdzić, że Stanisław August od początku nie dopuszczał do siebie myśli o możliwości rosyjskiej interwencji w sprawy Rzeczypospolitej. Założył błędnie, że wystarczy, jeśli swoje poczynania ograniczy do nieprowokowania dworu petersburskiego, wyciszania wszystkich napięć w stosunkach wewnętrznych i unikania wszystkiego, co mogłoby dać Rosji pretekst do interwencji. $Z$ tego powodu nie podjęto jakichkolwiek kroków skierowanych przeciwko rosyjskiej agenturze w Polsce. Król wyraźnie osłaniał też, przy wsparciu ze strony przywódców sejmowych, przebywających zagranicą malkontentów, liczac na ściagnięcie ich $z$ powrotem do kraju. Wobec takiego nastawienia monarchy nie dziwi więc to, że kompletnym niepowodzeniem zakończyły się też próby (w gruncie rzeczy bardziej pozorowane niż prawdziwe) nawiązania poważniejszych negocjacji $z$ dworem petersburskim. Stanisław August zwlekał też wyraźnie $z$ notyfikacją w Petersburgu nowej konstytucji. Dopiero 23 grudnia 1791 r., pod wpływem sugestii przebywającego w Dreźnie Adama Kazimierza ks. Czartoryskiego, który próbował nakłonić elektora saskiego do przyjęcia polskiej korony, sejm wyraził zgodę na dokonanie takiej notyfikacji w stolicy Rosji. Tego samego dnia król napisał do Katarzyny II. Akty notyfikacyjne, wysłane $z$ Warszawy 24 grudnia, Augustyn Deboli wręczył 3 stycznia 1792 r. wicekanclerzowi Iwanowi A. Ostermannowi. Katarzyna II nie uznała za stosowne udzielić Rzeczypospolitej jakiejkolwiek odpowiedzi. Dodajmy także, że na tym skończyły się w zasadzie aktywne działania dyplomacji polskiej w Petersburgu ${ }^{27}$.

27 Por. W. Smoleńs ki, Ostatni rok Sejmu..., s. 79, 238-240, 245; Z. An us ik, Rzeczpospolita wobec wojny..., s. 171-172; ide m, Kontrowersje wokót składu..., s. 102, 104-105; M. Ku charski, op. cit., s. 114-120; J. Łojek, Geneza i obalenie..., s. 219-221. Nie do przyjęcia jest natomiast z cała pewnością argumentacja Jerzego Michalskiego, który twierdził, że: „Stanisław August, któremu Konstytucja 3 Maja zwróciła i formalnie wpływ na politykę zagraniczną i który powierzył bezpośredni jej ster swemu zaufanemu, podkanclerzemu Chreptowiczowi, zwolennikowi orientacji rosyjskiej, nosił się $z$ zamiarem szukania porozumienia $z$ dworem petersburskim. Bał się jednak, że poczytane mu to zostanie za przejaw nielojalności, 
W tej sytuacji należałoby zadać pytanie, dlaczego nie doszło do nawiązania bezpośrednich rozmów między Warszawą a dworem rosyjskim? W pierwszych tygodniach po uchwaleniu Ustawy Rzadowej wszystko zdawało się przecież przemawiać za koniecznością podjęcia rozmów z Rosją. Dość szybko jednak, pod wpływem rozwoju sytuacji międzynarodowej (bardzo wiele król obiecywał sobie zwłaszcza po zbliżeniu prusko-austriackim i życzliwości cesarza Leopolda II dla Konstytucji 3 maja), Stanisław August zaczał żywić przekonanie, że do interwencji rosyjskiej w Polsce w ogóle nie dojdzie. Co zaś gorsze, przekonanie to zaczęli podzielać również przywódcy sejmowi. Najistotniejszym wszelako powodem, który uniemożliwił podjęcie negocjacji $z$ dworem rosyjskim, była jednak niechęć do takich negocjacji ze strony samego Stanisława Augusta. Wypada bowiem w tym miejscu stwierdzić, że w krótkim czasie po uchwaleniu Ustawy Rządowej król skoncentrował w swoich rękach wyłączne kierownictwo spraw zagranicznych, kontrolował działalność władz wykonawczych, jak też wpływał $\mathrm{w}$ istotnym stopniu na tok prac ustawodawczych. Słowem, osiagnął władzę, jakiej nie miał nigdy przedtem. Jest więc sprawą oczywistą, że nie miał najmniejszej ochoty na powrót do dawnej zależności od Petersburga, tym bardziej że nastroje opinii publicznej były zdecydowanie antyrosyjskie, $z$ czego doskonale zdawali sobie sprawę przywódcy sejmowi, usiłując przerzucić na Stanisława Augusta zadanie zainicjowania trudnych i niepopularnych w społeczeństwie rokowań. Zaniedbanie sprawy nawiązania kontaktów $z$ dworem petersburskim obciąża więc głównie Stanisława Augusta, ale nie bez winy byli również przywódcy Sejmu Wielkiego, którzy w pewnym momencie zaczęli podzielać królewskie przekonanie o tym, że sojusz austriacko-pruski stanowi wystarczająca gwarancję dla całości granic i ustroju Rzeczypospolitej ${ }^{28}$.

czy wręcz chęci nawrotu do sytuacji sprzed 1788 r. Toteż zaniechał myśli pisania do Katarzyny II i notyfikowania jej Konstytucji 3 Maja". Por. ide m, Dyplomacja polska..., s. 646.

${ }^{28}$ Przekonanie króla, że Rosja nie zdecyduje się na zbrojna interwencję w Rzeczypospolitej znajduje potwierdzenie $\mathrm{w}$ jego korespondencji $\mathrm{z}$ polskimi dyplomatami akredytowanymi przy dworach zagranicznych. Tak np. w styczniu 1792 r. Stanisław August pisał do Jerzego Potockiego w Sztokholmie: „Gdyby Rosja chciała nas zaczepić, w co nie wierzę, wtedy własny interes sąsiadów ich do obrony naszej wezwie”. W początkach lutego król przekonywał z kolei Potockiego, że zaplanowane na połowę tego miesiąca sejmiki pokrzyżują $z$ pewnością plany Rosji i przeciwnych Konstytucji 3 maja emigrantów. Kilka tygodni później perswadował znowu: „Z różnych przesłanek wnosić można, że Moskwa $z$ nami wojować nie będzie”. W począt- 
W tym miejscu musimy zaznaczyć, że po uchwaleniu Konstytucji 3 maja niemal wszystkie działania króla i przywódców sejmowych w zakresie polityki zagranicznej państwa pozostawały tajemnica dla ogromnej większości posłów i senatorów. Sejm z rzadka tylko był bowiem informowany o sytuacji na arenie międzynarodowej, a uczestnicy jego obrad dość słabo orientowali się w tych kwestiach. Przedmiotem zainteresowania izby poselskiej były natomiast poczynania przeciwników Ustawy Rządowej. Już 10 maja 1791 r., na wniosek pisarza polnego koronnego Kazimierza Rzewuskiego, jednomyślnie zostało uchwalone prawo nakazujace senatorom i posłom piastujacym urzędy wojskowe, a nieobecnym w Warszawie podlegać rozkazom Komisji Wojskowej. Celem tej uchwały było zmuszenie ich do złożenia przysięgi na konstytucję. Nie trzeba dodawać, że uchwała ta była wymierzona w pierwszym rzędzie w czołowych przeciwników Konstytucji 3 maja - generała artylerii koronnej Stanisława Szczęsnego Potockiego i hetmana polnego koronnego Seweryna Rzewuskiego. Nawiąując bezpośrednio do

kach kwietnia Stanisław August pisał z kolei do Jerzego Potockiego: „Po 16 kwietnia będziemy zabierać się do obronnych układów, co będzie tym łatwiejsze, kiedy Berlin i Wiedeń świeżo alians zawarli”. Już jednak w końcu tego miesiaca w kolejnym liście króla do posła w Sztokholmie znalazło się stwierdzenie: „My tu się tęgo zabieramy do obrony, ale myślę, że nie przyjdzie do tego, żeby wojnę przeciw nam rozpoczęła Moskwa”. Por. Stanisław August do J. Potockiego, Warszawa 21 I, 1 II, 22 II, 4 IV, 18 IV i 25 IV, BPAU, rkps 1653, k. 9-10, 13, 15, 17-18. O tym, że przywódcy sejmowi zdawali się podzielać królewskie przekonanie, iż sojusz austriacko-pruski stanowi wystarczająca gwarancję dla bezpieczeństwa Rzeczypospolitej, świadczy list Ignacego Potockiego do króla $z$ połowy marca $1792 \mathrm{r}$. Marszałek wielki litewski pisał: „Wiadomość o zgonie cesarza była i dla mnie powodem do rozmaitych uwag względem dalszego politycznego $z$ nami stosunku domu austryackiego, którego rzetelne interesa w tej porze zawsze jedne, w Rzeszy Niemieckiej bardziej jeszcze wymagają związków $z$ domami brandenburskim i saskim. Rzeczą jest rozwadze przeciwna wnosić ze straty cesarza zmienność systemu ostatecznego i obawiać się niepomyślnych dla nas skutków". Por. I. Potocki do Stanisława Augusta, Warszawa 16 III 1792, cyt. wg W. S moleń ski, Ostatni rok Sejmu..., s. 318. Por. też ibidem, s. 238, 240-241; Z. Anu sik, Misja polska..., s. 126; id e m, Kontrowersje wokót składu..., s. 103-104; idem, Rzeczpospolita wobec wojny..., s. 172-173; B. Leś nodorski, op. cit., s. 315. Wypada w tym miejscu dodać, że w marcu 1792 r., w obliczu ewidentnego już rozpadu sojuszu z Prusami, podjęto $\mathrm{w}$ Warszawie próbę zawarcia formalnego sojuszu $z$ dworem wiedeńskim. Była to jednak inicjatywa zdecydowanie spóźniona i w ówczesnej sytuacji nie mogła liczyć na jakiekolwiek poparcie w kręgach politycznych stolicy Austrii. Por. D. Nawrot, Próba reorientacji polskiej polityki zagranicznej w marcu 1792 r., [w:] Dyplomacja. Polityka. Prawo. Ksiega pamiatkowa ofiarowana Profesorowi Henrykowi Kocójowi $w$ siedemdziesiata rocznice urodzin, red. I. Panic, Katowice 2001, s. 64-73. 
tej uchwały, 22 czerwca 1791 r. Józef Miaskowski, poseł kaliski złożył wniosek, aby marszałkowie sejmowi zalecili oficerom pozostającym w służbie Rzeczypospolitej, a bawiącym zagranica, powrót do kraju i wykonanie przysięgi na konstytucję. Marszałek Stanisław Małachowski odparł, że kwestia ta należy do władzy wykonawczej i tylko on może na żądanie stanów zwrócić się do króla. W tym momencie kasztelan przemyski Antoni ks. Czetwertyński zaprotestował przeciwko użyciu przymusu względem tych, którzy nie sa zadowoleni $z$ nowej konstytucji. Gdy zaś następnie sam zaczął krytykować Ustawę Rządowa, sprowokował tym burzliwą dyskusję, która odwróciła uwagę sejmujacych od wniosku Miaskowskiego. Było to na rękę królowi, który egzekucją prawa z 10 maja nie chciał dodatkowo zadrażniać swoich stosunków ze Szczęsnym Potockim ${ }^{29}$.

Zgodnie $z$ linia polityczna Stanisława Augusta postępowano też w stosunku do innych przeciwników Konstytucji 3 maja. Na sesji w dniu 7 czerwca 1791 r. Stanisław Sołtyk, poseł krakowski, wystapił $\mathrm{z}$ mowa, w której ostrzegał, że w sejmie znajdują się jurgieltnicy obcych dworów, którzy na zlecenie swoich mocodawców wywołują niepotrzebne spory i opóźniają działania legislacyjne. Prosił zatem, poparty przez izbę, aby król nie szczędził starań i kosztów dla wyśledzenia tych, którzy na zgubę kraju zaprzedali się obcym. Król przyrzekł posłom, że dołoży wszelkich starań w tym względzie, ale jednocześnie podał w watpliwość „istnienie narzędzi służących obcym". Mimo jednoznacznego stanowiska opinii publicznej, która domagała się ścigania i karania zdrajców oraz wrogów Ustawy Rządowej, władze wykonawcze nie zrobiły niemal niczego w tej sprawie. Komisja Policji Obojga Narodów, która swoje urzędowanie rozpoczęła 4 lipca 1791 r., nie podjęła żadnych kroków przeciwko malkontentom. Nikogo nie postawiono przed sądem, nikomu nie przedstawiono zarzutów. Na przeciwników Konstytucji 3 maja starano się oddziaływać wpływem moralnym, unikając stosowania represji. $Z$ oczywistych względów na bezkarność mogli też liczyć zdeklarowani stronnicy dworu petersburskiego ${ }^{30}$.

${ }^{29}$ Por. W. S moleńs ki, Ostatni rok Sejmu..., s. 152-153; Zlecenie uum: seymowemu y konfederacyi o. n. marszałkom, VL, t. IX, s. 227; Ł. Kądziela, Rzewuski Kazimierz, [w:] PSB, t. XXXIV, s. 123; M. Złomska, Miaskowski Józef, [w:] PSB, t. XX, Wroclaw 1975, s. 541.

${ }^{30}$ Por. W. Smoleński, Ostatni rok Sejmu..., s. 69; M. Czeppe, E. Orman-M i chta, Sołtyk Stanisław, [w:] PSB, t. XL, Warszawa-Kraków 2000-2001, s. 426. 
Dnia 28 czerwca 1791 r. posłowie rozjechali się do domów na przerwę wakacyjna. Obrady sejmowe zalimitowano do 15 września. W niedługim czasie po wznowieniu działalności sejmu powrócono do sprawy czołowych malkontentów. Wieczorem 23 października kurier przywiózł bowiem do Warszawy wiadomość o śmierci Grigorija A. ks. Potiomkina. W zwiazku z tym, na sesji w dniu 24 października 1791 r. Michał Zabiełło, poseł inflancki, powołując się na prawo z 10 maja, zażądał złożenia przez Szczęsnego Potockiego i Seweryna Rzewuskiego przysięgi na Konstytucję 3 maja oraz przedstawienia wyjaśnień dotyczących ich pobytu w Jassach. Konstanty Jelski, poseł starodubowski złożył natomiast wniosek o pozbawienie pensji tych urzędników, którzy bez zezwolenia Rzeczypospolitej bawia zagranica. Adam Kazimierz ks. Czartoryski zaproponował rozstrzygnięcie sprawy obu malkontentów przez sąd i wniósł o to, aby propozycja Zabiełły była rozpatrywana $z$ materiami wojskowymi. Po dłuższej dyskusji zgodzono się jednak ostatecznie na to, aby obu malkontentów wezwać do kraju. W myśl uchwały sejmowej, 25 października król wystosował rozkaz do hetmana polnego, a Komisja Wojskowa do generała artylerii, aby w ciagu trzech miesięcy od 27 października $1791 \mathrm{r}$. stawili się do wypełniania swoich obowiązków. W dniu 5 grudnia ponowiono rozkazy króla i Komisji Wojskowej do Rzewuskiego i Potockiego. Następnego dnia doszło zaś do kolejnego spięcia w izbie poselskiej. Tadeusz Kościałkowski, poseł wiłkomierski, w ostrych słowach potępił bowiem knowania malkontentów w Jassach. Jan Nepomucen Zboiński, poseł dobrzyński, przedstawił zaś projekt, by nie przyjmować do akt publicznych żadnych manifestów i protestacji przeciwko sejmowi i konstytucji, a zarówno protestujacych, jak i przyjmujących do akt tego rodzaju dokumenty karać i ogłosić burzycielami porządku publicznego. W czasie burzliwej dyskusji malkontentów bronili kasztelan przemyski Antoni ks. Czetwertyński oraz Stanisław Hulewicz, poseł wołyński. Kazimierz Nestor Sapieha, marszałek Konfederacji Litewskiej ręczył za lojalność swojego wuja, hetmana Franciszka Ksawerego Branickiego. Król starał się łagodzić nastroje i nie dopuścić do podjęcia uchwały godzącej w przeciwników Ustawy Rządowej, ale ostatecznie sejm uchwalił „Deklarację względem manifestów” ${ }^{31}$.

${ }^{31}$ Por. W. S moleński, Ostatni rok Sejmu..., s. 187-191, 197-203; J. Łojek, Geneza i obalenie..., s. 228-229; E. Ros tworowski, Jelski Konstanty, [w:] PSB, t. XI, Wrocław-Warszawa-Kraków 1964-1965, s. 154; Głos Jaśnie Wielmożnego Jegomości Tadeusza Kościałkowskiego z Zyndranów, starosty Czotyrskiego, posła 
Dnia 2 stycznia 1792 r. Komisja Wojskowa wystosowała trzeci i ostatni rozkaz dla Szczęsnego Potockiego. Król przypuszczał, że jeśli generał artylerii koronnej okaże się nieposłuszny, sejm nie będzie mu dłużej pobłażać. Jednak nawet wówczas Stanisław August wciąż się łudził, że perswazjami uda mu się przekonać malkontentów do uznania nowej konstytucji. Tego samego dnia napisał więc list do Szczęsnego i wysłał z nim do Jass Stanisława Kostkę Potockiego. Zanim ten ostatni dotarł jednak do miejsca swojego przeznaczenia (zjawił się w Jassach 13 stycznia), generał artylerii koronnej zdążył już odpowiedzieć (10 stycznia) odmownie na ostatni rozkaz Komisji Wojskowej. Misja Stanisława Kostki Potockiego nie przyniosła więc pożądanych przez króla rezultatów. Tymczasem wyczerpała się również cierpliwość posłów. Na sesji w dniu 26 stycznia 1792 r. Michał Zabiełło, przypomniawszy, że zbliża się ostateczny termin wyznaczony Potockiemu i Rzewuskiemu do złożenia przysięgi na konstytucję, zażądał, aby w dniu następnym odczytane były w izbie raporty w tej sprawie Straży Praw i Komisji Wojskowej. Dnia 27 stycznia marszałek Stanisław Małachowski zaproponował zalimitowanie obrad sejmowych, ale Zabiełło powtórzył swój wniosek. Odczytano więc rozkazy przesłane malkontentom oraz ich odpowiedzi. Poseł inflancki Julian Ursyn Niemcewicz wygłosił wówczas żarliwa mowę oskarżycielska pod adresem obu zuchwałych dygnitarzy i wniósł o zniesienie buław polnych i odebranie urzędu generała artylerii koronnej Szczęsnemu Potockiemu. W obronie malkontentów przemówił prymas Michał Poniatowski. Bronili ich również marszałek Kazimierz Nestor Sapieha, poseł wołyński Jan Zagórski, poseł wiłkomierski Józef Dominik Kossakowski oraz kasztelan przemyski Antoni ks. Czetwertyński. Król radził, żeby zająć się ta sprawa dopiero po limicie obrad. Wniosek Niemcewicza poparli natomiast posłowie: wiłkomierski Tadeusz Kościałkowski, liwski Pius Kiciński, krakowski Stanisław Sołtyk i brasławski Tomasz Wawrzecki. Ich stanowisko zaakceptowała też zdecydowana większość sejmujących. W obliczu nieuchronnej porażki w głosowaniu, obrady opuścili ci senatorowie i posłowie, którzy byli przeciwni karaniu malkontentów, a pozostali na sali obrad uchwalili ustawę w redakcji zgłoszonej przez Niemcewicza. Król nie był z pewnością

Wiłkomierskiego na sesyi seymowey dnia 6 Grudnia 1791 r. miany, Warszawa [1791]; B. Krakowski, Kościałkowski Tadeusz, [w:] PSB, t. XIV, Wrocław-Warszawa-Kraków 1967-1968, s. 397; Deklaracya względem manifestów, VL, t. IX, s. 367. 
zadowolony, gdyż stanowiło to odstępstwo od przyjętej przez niego linii politycznej, ale opinia publiczna przyjęła tę uchwałę sejmowa $z$ dużym zadowoleniem. Dnia 28 stycznia 1792 r., ze względu na mające się odbyć w lutym sejmiki deputackie i gospodarskie, ogłoszono zalimitowanie sejmu do 15 marca $^{32}$.

W dniu 14 lutego 1792 r. odbyły się w Rzeczypospolitej sejmiki deputackie i gospodarskie. Były one swoistym referendum, w którym szlachta po raz pierwszy miała okazję wyrazić swój stosunek do Konstytucji 3 maja. Wyniki sejmików oznaczały wielkie zwycięstwo zwolenników Ustawy Rządowej. Około 90\% zgromadzeń ją bowiem zaakceptowało. Opozycja polityczna, która opanowała nieco ponad $10 \%$ sejmików, zdobyła się tylko na przemilczenie Konstytucji 3 maja. I chociaż nastoje niezadowolenia $z$ zamachu trzeciomajowego były w gruncie rzeczy nieco większe (17\% sejmików uchwaliło jedynie podziękowania za uchwalenie konstytucji), to nie zmienia to faktu, że niemal 75\% sejmików zostało opanowanych przez obóz konstytucyjny. Zasadniczy cel zwołania sejmików lutowych został więc osiagnięty. Prowincjonalna szlachta zaakceptowała Ustawe Rządowa. Tak pomyślne wyniki referendum trzeciomajowego obudziły w królu nadzieję, że Moskwa powstrzyma się od wrogich kroków, a elektor saski zgodzi się wreszcie przyjąć koronę ${ }^{33}$.

Nadzieje Stanisława Augusta okazały się jednak płonne. Brak odpowiedzi Petersburga na notyfikację Konstytucji 3 maja skutecznie zablokował bowiem rokowania $z$ dworem drezdeńskim, który jako warunek sine qua non wysuwał żądanie uzyskania formalnej zgody Katarzyny II na przyjęcie przez elektora polskiej korony. Ze stolicy Rosji Augustyn Deboli przesyłał zaś coraz bardziej niepokojące wiadomości. Mimo to król jednak nadal zwlekał i dopiero pod koniec marca zaczął myśleć o podjęciu jakichś przygotowań do obrony. Na sesji w dniu 16 kwietnia 1792 r. przedstawiono posłom sprawozdanie ze stanu negocjacji $z$ elektorem saskim oraz przekazano informację, że Rosja oświadczyła dworom sąsiedzkim, że nie uznaje Konstytucji 3 maja i chce utrzymania w całości formy rzadu

32 Por. W. S moleńs ki, Ostatni rok Sejmu..., s. 210-228, 230-231; Stanisław August do Franciszka Bukatego, Warszawa 7 i 28 I 1792, W. Kalinka, Ostatnie lata..., cz. 2, s. 208, 210-211; B. Grochulska, Potocki Stanisław Kostka, [w:] $P S B$, t. XXVIII, s. 162; I. Homola, Kossakowski Józef Dominik, [w:] PSB, t. XIV, s. 275; Deklaracya względem osób woyskowych nieprzysięgłych $i$ zniesienia bulaw polnych, VL, t. IX, s. 403.

${ }^{33}$ Por. W. Szczygielski, Referendum trzeciomajowe. Sejmiki lutowe 1792 roku, Łódź 1994, s. 397; W. S moleń ski, Ostatni rok Sejmu..., s. 298-299. 
zagwarantowanej w 1775 r. Minister spraw zagranicznych w Straży dodał również, że dwór petersburski zamierza przeprowadzić swoje wojska (wracające $z$ Mołdawii po zakończeniu wojny $z$ Turcja) przez terytorium Rzeczypospolitej. Kiedy jednak wniesiono pod obrady projekt ustawy upoważniającej króla do rozpoczęcia działań zmierzających do wzmocnienia obronności kraju, posłowie: krakowski August Otwinowski, wołyński Ignacy Krzucki i trocki Ignacy Siwicki żąali deliberacji. Energiczne wsparcie projektu przez Adama Szydłowskiego, posła mielnickiego, Kazimierza Nestora Sapiehę oraz samego króla sprawiło jednak, że ostatecznie przeszedł on jednomyślnie. Na mocy podjętej wówczas uchwały powierzono królowi kierownictwo spraw wojskowych i upoważniono go do ściagnięcia z zagranicy do armii polskiej kilku generałów (jednego, dwóch lub trzech) oraz doświadczonych oficerów do korpusów artylerii i inżynierii. Komisji Wojskowej polecono natomiast zaciagnąc kredyt w wysokości $30 \mathrm{mln}$ złp, który miano zabezpieczyć na funduszu mającym powstać $z$ planowanej sprzedaży starostw. Na wniosek Stanisława Sołtyka, posła krakowskiego, uchwalono zakomunikowanie tej uchwały w Dreźnie, w Wiedniu i w Berlinie. Na sesji w dniu 21 kwietnia 1792 r. król odczytał w izbie wyjątki $z$ ostatnich depesz nadesłanych przez Debolego z Petersburga. Pominał jednak nazwiska Szczęsnego Potockiego i Seweryna Rzewuskiego. Stwierdził przy tej okazji, że generał-lejtnant Szymon Kossakowski zapewniał go w swoich listach, że na wypadek wybuchu wojny złoży rezygnację ze służby rosyjskiej. Zalecał unikanie postawy wojowniczej. Dawał nadzieję na zażegnanie kryzysu w sposób pokojowy, ale zachęcał do kontynuowania zbrojeń. Tego dnia jednomyślnie uchwalono dwie ustawy. Pierwsza upoważniała króla do podjęcia działań niezbędnych do powiększenia stanu osobowego armii do stu tysięcy żołnierzy. Druga zezwalała na przyjęcie do służby w armii polskiej 20 oficerów z zagranicy ${ }^{34}$.

${ }^{34}$ Por. W. Smoleński, Ostatni rok Sejmu..., s. 248-249, 347-350, 354-356; Deklaracya doczesna oraz Umieszczenie $w$ woysku Rzeczypospolitey dwudziestu officyerów z służby zagraniczney, VL, t. IX, s. 423-424. Warto może w tym miejscu zaznaczyć, że mimo podjęcia przygotowań do obrony kraju, Stanisław August cały czas miał nadzieję, że nie dojdzie do wybuchu wojny. W tym duchu pisał bowiem w cytowanym już liście do posła Rzeczypospolitej w Sztokholmie. Por. Stanisław August do J. Potockiego, Warszawa 25 IV 1792, BPAU, rkps 1653, k. 15; Z. A n u sik, Misja polska..., s. 126-127. Podobne sformułowania znalazły się także w liście króla do Franciszka Bukatego w Londynie: „Z Wiednia miałem wczoraj wiadomość (równie jak i z Berlina pisza), że w obydwóch tych dworach jest perswazya, 
Zaraz po uroczystych obchodach rocznicy uchwalenia Konstytucji 3 maja sejm podjął dalsze działania zmierzajace do wzmocnienia obronności kraju. Dnia 7 maja 1792 r., na wniosek Ignacego Potockiego, zastępującego w Straży nieobecnego ministra wojny, jednomyślnie uchwalono sformowanie dwóch pułków tatarskich, dwóch pułków kozackich oraz czterech batalionów ochotników. W dniu 14 maja podjęto decyzję o wcieleniu wszystkich milicji magnackich do armii regularnej. Właścicielom ziemskim zezwolono utrzymywać siłę zbrojną w liczbie nie większej niż 40 ludzi. Zachęcano do dobrowolnych ofiar na obronę i do ochotniczego wstępowania do armii. Na sesji w dniu 18 maja przeszedł projekt opisania Komisji Wojskowej. Przed samym głosowaniem w tej sprawie Jakow Bułhakow doręczył Joachimowi Chreptowiczowi deklarację dworu rosyjskiego $z$ wyjaśnieniem powodów wkroczenia armii imperatorowej w granice Rzeczypospolitej. Wieść ta błyskawicznie rozeszła się po Warszawie, wywołujac konsternację i popłoch. Dnia 19 maja 1792 r. przywódcy sejmu zebrali się na naradzie u podkanclerzego koronnego Hugona Kołłątaja. Podjęto wówczas decyzję o odczytaniu deklaracji rosyjskiej na najbliższej sesji sejmowej $z$ udziałem arbitrów. Postanowiono też zapytać posłów pruskiego, austriackiego i saskiego, czy Polska może liczyć na pomoc ich dworów. Na tym samym spotkaniu uzgodniono również, że Stanisław August obejmie naczelne dowództwo nad wojskiem. Dnia 21 maja, w poniedziałek, deklaracja dworu petersburskiego została odczytana na posiedzeniu sejmu. Zaraz potem przemówił król. Zapowiedział odwołanie się do pomocy ze strony życzliwych sąsiadów - Prus, Austrii i Saksonii. Stwierdził jednak również, że nie zaniedba niczego, co mogłoby otworzyć drogę do rozpoczęcia rokowań $z$ cesarzowa i zażegnania kryzysu raczej piórem, niż orężem. Na zakończenie swojego przemówienia poprosił zaś posłów o szybkie dokończenie rozpoczętych już spraw. Dnia 22 maja sejm powierzył Stanisławowi Augustowi naczelne dowództwo armii i przyjał projekt nowego etatu wojskowego ${ }^{35}$.

iż jednak Moskwa hostilitates przeciwko Polsce nie rozpocznie, ponieważ poczyniła kwestye o nas do tych Dworów, a te wzajemnie do niej, więc jeszcze kilka tygodni może w niepewności dyszeć nam przyjdzie”. Por. Stanisław August do F. Bukatego, Warszawa 25 IV 1792, W. Kalin ka, Ostatnie lata..., cz. 2, s. 216.

${ }_{35}$ Por. W. S moleńs ki, Ostatni rok Sejmu..., s. 393-400; Uformowanie dwóch pułków Tatarskich, dwóch Kozackich i czterech batalionów ochotników, VL, t. IX, s. 438-439; Wyprawy obronne, ibidem, s. 443-445; Głos Jego Królewskiej Mości dnia 21 maja roku 1792, [Warszawa 1792]. 
Na sesji w dniu 24 maja 1792 r. Stanisław Olędzki, poseł żmudzki, prosił króla o wyjawienie nazwisk malkontentów knujących w Petersburgu spisek przeciwko Rzeczypospolitej. Pisarz polny koronny Kazimierz Rzewuski, poseł podolski, żądał zdemaskowania posłów i senatorów utrzymujących stosunki $z$ dworem imperatorowej. Król nikogo jednak wymienić nie chciał. Konstanty Jelski, poseł starodubowski, zaproponował wezwanie Szczęsnego Potockiego, Seweryna Potockiego i kilku innych malkontentów przebywajacych w stolicy Rosji do stawienia się w przeciagu trzech tygodni na sąd sejmowy. Stanisław August tonował jednak nastroje i doradzał powściagliwość w karaniu. Zaraz po wystapieniu króla jednomyślnie podjęto uchwałę nakazująca powrót do kraju Polakom pozostającym w służbie rosyjskiej. Rodaków znajdujących się w szeregach armii rosyjskiej ogłaszano nieprzyjaciółmi ojczyzny. Za nieprzyjaciół ojczyzny poczytani mieli być również ci, którzy pierwsi zawiązali spisek przeciwko sejmowi i władzom Rzeczypospolitej, jeśli nie odstąpią od niego w przeciagu sześciu tygodni. Zagrożono wreszcie utrata praw obywatelskich, czci i kara śmierci wszystkim uczestnikom wrogich konspiracji. Na tej samej sesji ustanowiono też nadzwyczajny sąd sejmowy dla karania zdrajców. W dniu 24 maja uchwalono podwyższenie podatków. Dzień później, 25 maja ustanowiono fundusz w wysokości 1,5 mln złp dla żołnierzy, którzy wyróżnią się w walce, a wdowom i sierotom po poległych zapewniono połowę ich gaży. Tego samego dnia król wydał utrzymana w wojowniczym tonie odezwę do wojska. Dnia 29 maja 1792 r. na sesji przedpołudniowej przedstawiono sejmowi niezbyt szczęśliwie sformułowana („w treści i formie nieudolna”) odpowiedź na deklaracje rosyjską. Tego samego dnia sejm przyjał zredagowany przez Grzegorza Piramowicza i Hugona Kołłataja uniwersał do narodu, a następnie, po burzliwej dyskusji, podją jednomyślną decyzję o zalimitowaniu swoich obrad na czas trwania wojny ${ }^{36}$.

Po zalimitowaniu obrad sejmowych pełna odpowiedzialność za losy państwa spoczęła w rękach Stanisława Augusta. Król, podobnie zreszta jak przywódcy stronnictwa patriotycznego, myślał ra-

\footnotetext{
${ }^{36}$ W. Smoleński, Ostatni rok Sejmu..., s. 406-413; M. Złomska, Olędzki (Olendzki) Stanisław, [w:] PSB, t. XXIII, Wrocław 1978, s. 797; Kommenda I.K. Mości nad woyskiem Rzeczypospolitey, VL, t. IX, s. 447; Deklaracya względem stanu teraźnieyszego Rzeczypospolitey, ibidem, s. 449-450; Pobór generalny, ibidem, s. 450; Nadgroda dzieł walecznych, ibidem; Sad seymowy extraordynaryiny, ibidem, s. 452; Kommissya woyskowa oboyga narodów, ibidem, s. 457-468; Limita seymu, ibidem, s. 469-470.
} 
czej o rozpoczęciu negocjacji z dworem petersburskim niż o prowadzeniu energicznych działań wojennych. Bardziej dla zachowania pozorów niż $z$ wiarą w skuteczność tych działań zwrócił się o pomoc do obu dworów niemieckich. Dnia 22 maja Adam Kazimierz ks. Czartoryski pojechał do Wiednia, żeby prosić o pomoc władce Austrii ${ }^{37}$. W dniu 25 maja Joachim Chreptowicz wręczył posłowi pruskiemu w Warszawie Girolamo Lucchesiniemu notę z prośbą o pomoc zgodnie $z$ warunkami sojuszu z 29 marca 1790 r. Kilka dni później (31 maja) Ignacy Potocki wyjechał zaś do Berlina na rozmowy $z$ królem pruskim ${ }^{38}$. Ku zdumieniu postronnych

37 Tylko niepoprawny optymista mógł wierzyć w to, że dwór wiedeński, uwikłany od 20 IV 1792 r. w wojnę $z$ rewolucyjna Francja, będzie chciał i mógł udzielić Rzeczypospolitej jakiejś pomocy. O braku jakiejkolwiek nadziei na pomyślny rezultat misji księcia Adama Czartoryskiego wiedzieli zarówno król, jak i wszyscy przywódcy sejmowi.

${ }^{38}$ Król pruski Fryderyk Wilhelm II już 9 I 1792 r. podjął decyzję, że nie wystapi w obronie Rzeczypospolitej. W początkach zaś lutego, kiedy finalizowano podpisany w Wiedniu przedwstępny układ sojuszniczy między Austrią i Prusami, dyplomacja pruska wymogła wprowadzenie do ostatecznego tekstu traktatu zmiany w punkcie dotyczącym państwa polsko-litewskiego. Zamiast stwierdzenia, że połączone sojuszem państwa będą wspólnie bronić (obecnej) konstytucji polskiej, znalazło się sformułowanie o podtrzymaniu wolnej konstytucji Polski, co otwierało szerokie pole do interpretacji tego zapisu. Jeszcze w tym samym miesiącu dyplomacja pruska rozpoczęła też w Petersburgu działania zmierzające do wybadania stanowiska Rosji wobec pomysłu dokonania kolejnego rozbioru Rzeczypospolitej. Por. S. Askenazy, op. cit., s. 173-175, 184-186; W. Smoleński, Ostatni rok Sejmu..., s. 253. Dodajmy w tym miejscu, że S. Askenazy nie miał najmniejszych nawet wątpliwości, że Ignacy Potocki zdawał sobie w pełni sprawę z beznadziejności swoich wysiłków w celu nakłonienia Fryderyka Wilhelma II do wypełnienia jego zobowiązań sojuszniczych. Por. idem, op. cit., 196-197. Zdaniem W. Smoleńskiego „Polacy nie wiedzieli o zmianie stanowiska dworu berlińskiego”, a Ignacy Potocki, podejmując się misji berlińskiej, „niedość jasno zdawał sobie sprawę z sytuacji". Por. id e m, op. cit., s. 253-254, 425. Jest to jednak stanowisko zupełnie pozbawione podstaw, gdyż przynajmniej od początku maja $1792 \mathrm{r}$. (w moim przekonaniu zaś znacznie wcześniej) wiedziano w Warszawie, że Prusy nie uznaja interwencji Katarzyny II za casus foederis. Por. J. Michalski, Dyplomacja polska..., s. 648; Z. Anusik, Kontrowersje wokół składu..., s. 114. Warto również zauważyć, że o zmianie stanowiska Prus wiedział również Stanisław August Poniatowski. Jeszcze 11 IV 1792 r. pisał on co prawda do Franciszka Bukatego w Londynie, że: „do wojny jednak otwartej podobno nie przyjdzie. A gdyby zaś do niej przyszło i zaczepnej ze strony Moskwy, król pruski, rad nie rad, musiałby nas po staremu bronić, bo podług aliansu, jest obowiązany bronić naszej independencyi”. Już jednak 9 V król tak oto pisał o postępowaniu Fryderyka Wilhelma II do tego samego adresata: „Otóż, chciałby on nas nastraszyć, okazując, że nas zupełnie opuszcza, i że tak rzekę zdradza, abyśmy się zlękli tak dalece, żebyśmy sami ultro na klęczkach poszli do Moskwy, spodziewając się, że ona byle wymogła na nas 
obserwatorów, po rozpoczęciu wojny z Rosją nie zażądano wyjazdu z Warszawy posła rosyjskiego Jakowa Bułhakowa, z którym zamierzano prowadzić tajne pertraktacje ${ }^{39}$. Tymczasem trwały też

opuszczenie tronu sukcesyjnego, reszty praw 3 maja nam dozwoli". Por. Stanisław August do F. Bukatego, Warszawa 11 IV i 9 V 1792, W. Kalinka, Ostatnie lata..., cz. 2, s. 214-215, 217. Jeszcze wyraźniej swoje przekonanie o odstępstwie Prus król wyartykułował w swoim liście do posła polskiego w Sztokholmie. Pisał w nim, że: „dostrzegł, że deklaracja rosyjska [z 18 V 1792 r. - przyp. Z.A.] uczyniła na Prusach takie wrażenie, że atakować będą nie tylko ustawę 3 maja, ale i całe dzieło sejmowe". Por. Stanisław August do J. Potockiego, Warszawa 23 V 1792, BPAU, rkps 1653, k. 23. O tym, że Prusy nie udziela Polsce pomocy, wiedział także poseł polski w Berlinie Stanisław Paweł ks. Jabłonowski. Jeszcze w maju 1792 r. sejm nie był jednak świadomy izolacji politycznej Rzeczypospolitej. Ostrzeżenia Jabłonowskiego kierowane do króla i Chreptowicza zachowano bowiem w tajemnicy. Por. M. Kucharski, op. cit., s. 125-128; Z. Anusik, Rzeczpospolita wobec wojny..., s. 183.

39 Bardzo krytycznie o poczynaniach króla i Joachima Chreptowicza w pierwszych dniach konfliktu z Rosją pisał Ignacy Potocki: „Jest widoczną rzeczą, iż nasz minister do interesów zagranicznych ma jedynie na celu pogodzić jak najrychlej króla $z$ Moskwą. I lubo czasami nawet mówi nawet $z$ żywością: "trzeba się bronić, trzeba tęgości", kiedy przychodzi do kroków szczególnych i czynów, albo je opuszcza, albo osłabia. Od 18 maja żaden nie jest ekspediowany kurier, ani do Berlina, ani do Wiednia, do Drezna, do Stambułu. W okolicznościach daleko mniejszej wagi byliśmy baczniejsi i śpieszniejsi. Sa przyczyny, dla których obrona nietęgo idzie, ale nie masz żadnej, która by usprawiedliwiała opieszałość negocjacji. Szczerze, bo w wynurzeniu przyjacielskim cię ostrzegam, iż tym torem wkrótce wprawieni będziemy w potrzebę podania pokornej supliki do imperatorowej moskiewskiej". Por. I. Potocki do Stanisława Małachowskiego, Warszawa 28 V 1792, J. Łojek, Geneza i obalenie..., Aneks X, s. 458. Podobnie komentował poczynania kierownictwa dyplomacji polskiej poseł polski w Sztokholmie: „Cóż ci panowie robia, to nie do pojęcia. Nikogo nie odsyłaja, listów kredencjonalnych nie przysyłaja, a Stackelberg magno motu o posiłki prosi, a Chreptowicz ani mi rozkazów nie daje". Por. J. Potocki do I. Potockiego, Sztokholm 25 V 1792, Archiwum Główne Akt Dawnych w Warszawie [dalej: AGAD], Archiwum Publiczne Potockich [dalej: APP] nr 227, s. 450-451. Wyjaśnijmy przy tej okazji, że Potocki potrzebował nowych listów uwierzytelniających, ponieważ stare straciły ważność po śmierci Gustawa III w dniu 29 III 1792 r. Ambasador Katarzyny II w Sztokholmie (Otto Magnus von Stackelberg) zabiegał zaś o posiłki szwedzkie przeciwko Rzeczypospolitej z tej racji, że zmarły król Szwecji sprzymierzył się z cesarzową traktatem drottningholmskim w październiku $1791 \mathrm{r}$. Jeszcze bardziej symptomatyczny jest jednak kolejny list Jerzego Potockiego do marszałka wielkiego litewskiego: „Jak widzę, u nas się bija, ale kroki jak widzę błędnie się zaczynaja, bo nie wiem za co Bułhakowowi dozwalaja siedzieć. Ta myśl tak trudna jest do eksplikacji mojej, że słowem $z$ tej polityki wszyscy się śmieją i ja $z$ niemi, bo widzę, że to nigdzie się nie robi. Jednym słowem, według mego mniemania jest to sromota wielka i prawdziwie rzecz niepojęta". Por. J. Potocki do I. Potockiego, Sztokholm 15 VI 1792, AGAD, APP nr 227, s. 453. Dodajmy, że Potocki komentuje tutaj odbiór w stolicy Szwecji decyzji władz polskich, zezwalających posłowi rosyjskiemu na dalszy pobyt 
gorączkowe narady króla z przywódcami sejmowymi. W czasie tych spotkań dyskutowano nie nad tym, jak skutecznie prowadzić wojnę, ale nad tym, w jaki sposób rozpocząć negocjacje $z$ Katarzyną II $\mathrm{w}$ sprawie zawieszenia broni i utrzymania w mocy przynajmniej części artykułów Konstytucji 3 maja $^{40}$. Ostatecznie, po wstępnym uzgodnieniu treści swojego wystapienia $z$ przywódcami stronnictwa patriotycznego i z czynnym współudziałem posła rosyjskiego, który wpłynał na dokonanie pewnych zmian w pierwotnym tekście, 22 czerwca 1792 r. Stanisław August wystosował list do cesarzowej, proponując koronę dla jej małoletniego wnuka, wielkiego księcia Konstantego, oraz równocześnie wysuwając ofertę podpisania polsko-rosyjskiego traktatu sojuszniczego $z$ korzystnym dla obu stron układem handlowym. Stanisław August prosił także Katarzynę II o jak najszybsze przerwanie działań wojennych ${ }^{41}$. Odpowiedź rosyjska, datowana w Petersburgu na 13 lipca 1792 r., przyjść miała dopiero po miesiącu nerwowych oczekiwań. Imperatorowa podtrzymała w niej wszystkie argumenty zawarte $\mathrm{w}$ deklaracji

w Warszawie mimo rozpoczęcia przez dwór petersburski działań wojennych przeciwko Rzeczypospolitej.

${ }^{40}$ Warto w tym miejscu przypomnieć opinię Emanuela Rostworowskiego, który pisał, że przywódcy stronnictwa patriotycznego naiwnie sadzili, że dysponuja znakomitym argumentem politycznym: oferta korony polskiej dla wnuka Katarzyny II, wielkiego księcia Konstantego. Przytoczona przez tego autora wypowiedź Adama Kazimierza ks. Czartoryskiego, który w grudniu 1791 r. stwierdził, że „w wypadku odmowy elektora [saskiego w kwestii przyjęcia korony - przyp. Z.A.] najmądrzejszym krokiem Polski będzie oświadczyć imperatorowej: zachowaj nam Konstytucję, a my zgodzimy się na oddanie tronu twojemu wnukowi”. Por. E. Rostworowski, Ostatni król..., s. 288. W moim przekonaniu wystapienie Czartoryskiego należy jednak interpretować jako wyraz pewnego nacisku na Fryderyka Augusta III oraz krok przynaglający Stanisława Augusta do podjęcia wreszcie rozmów $z$ Rosją i oswajający po trochu opinię publiczna z myślą o konieczności podjęcia rokowań z imperatorową. Należy w tym miejscu podkreślić również to, że król niezbyt życzliwie odniósł się do wystapienia Czartoryskiego, ponieważ jeszcze przez dłuższy czas nosił się z myślą zapewnienia korony jednemu ze swoich bratanków. Do pomysłów zaoferowania korony polskiej wnukowi Katarzyny II wrócili przywódcy stronnictwa patriotycznego (tym razem $z$ pełna akceptacja ze strony króla) dopiero w obliczu wojny z Rosją. Zgadzając się ze stwierdzeniem E. Rostworowskiego, że politycy polscy zdecydowanie przeceniali atrakcyjność polskiej korony na europejskim rynku dynastycznym, trudno jednak zaakceptować bez zastrzeżeń jego tezę, że wojna polsko-rosyjska 1792 r. była jedynie ze strony polskiej demonstracją, mająca ułatwić rokowania o przekazanie korony wielkiemu księciu Konstantemu. Por. idem, Maj 1791 - maj 1792. Rok monarchii konstytucyjnej, Warszawa 1985, s. 35; oraz i d e m, Ostatni król..., s. 288-289. Por. też Z. A n u sik, Kontrowersje wokół składu..., s. 106, 115.

${ }^{41}$ Szerzej w tej kwestii por. J. Łojek, Geneza i obalenie..., s. 350-366. 
z 18 maja i żądała, aby król niezwłocznie przystapił do konfederacji targowickiej ${ }^{42}$.

Wbrew twierdzeniu większości historyków polskich, którzy uznali, że propozycje zawarte w liście Stanisława Augusta były śmieszne, spóźnione i absolutnie nie do przyjęcia dla dworu petersburskiego, w Carskim Siole trwały długie i ożywione dyskusje między doradcami cesarzowej, zanim ostatecznie zdecydowano się na zredagowanie negatywnej odpowiedzi Katarzyny II na list Stanisława Augusta. Dobrze zorientowany w tamtejszych stosunkach ambasador Szwecji w Petersburgu - Curt von Stedingk w depeszy z 14 lipca 1792 r. pisał wyraźnie o dużym wrażeniu, jakie list Stanisława Augusta wywarł na Katarzynie II. Jego zdaniem cesarzowa miała być bardzo zadowolona ze sposobu, w jaki został on zredagowany. Ambasador powtarzał także dominująca w stolicy Rosji opinię, że Katarzyna II, zniecierpliwiona przedłużającą się wojną i znudzona już cała sprawa, pod wpływem sugestii swoich starych doradców (Bezborodko, Ostermann, Woroncow), gotowa była odstapić od niektórych pretensji względem Polski. Jednak Płaton A. Zubow, wspierany radami przez Morkowa i Popowa, wykazał cesarzowej, że jej honor wymaga, aby podtrzymała partię, którą do tej pory protegowała i nie zmieniała niczego $\mathrm{w}$ twardych warunkach, jakie wcześniej zamierzano narzucić polskiemu królowi. Przy tej okazji Stedingk pozwolił sobie wyrazić współczucie dla losu Stanisława Augusta, nieszczęśliwego monarchy, zmuszonego do rokowań ze swoimi zbuntowanymi poddanymi. Ubolewał także nad losem Polski, która ponownie miała się dostać pod rosyjskie jarzmo. Nie wykluczał też jej przyszłego rozbioru, przewidując, że król pruski $z$ pewnościa będzie chciał uczestniczyć w tej nowej katastrofie, która zawisła właśnie nad Rzeczapospolita ${ }^{43}$. Warto zwrócić $\mathrm{w}$ tym miejscu uwage na to, że również Jerzy Potocki w Sztokholmie wiedział o istnieniu dwóch zwalczających się koterii w najbliższym otoczeniu cesarzowej. Już 20 lipca 1792 r. w liście do Stanisława Augusta umieścił bowiem następujące sformułowanie: „Imperatorowa akceptowała poczatkowo zawieszenie broni, ale Morkow intrygant wpłynął na zmianę tej decyzji”. Tydzień później Potocki pisał ponownie: „Po oddanym liście WKM z początku zaraz Imperatorowa

42 Por. ibidem, s. 406-408.

43 Por. C. von Stedingk do Gustawa IV Adolfa, Petersburg $3 / 14$ VII 1792, apostille, RA, Muscovitica vol. 453. Por. też Z. Anusik, Rzeczpospolita wobec wojny..., s. 181-182. 
się nakłaniała, pan Ostermann i Bezborodko byli tego zdania, ale Zubow, Morkow i Popow wcale ją odmienili" ${ }^{\prime 4}$.

Szczupłość sił zbrojnych, którymi dysponowała Rzeczpospolita, a przede wszystkim brak wiary w zwycięstwo wśród ludzi kierujacych jej nawa państwowa, przesądziły ostatecznie o klęsce Polaków w wojnie $z$ Rosja ${ }^{45}$. Dnia 24 lipca 1792 r. Stanisław August postanowił złożyć akces do konfederacji targowickiej. Wydaje się, że krok ten mógł zostać (po pewnych wahaniach) zaaprobowany przez przywódców stronnictwa patriotycznego, aczkolwiek na posiedzeniu Straży Praw (w poszerzonym składzie) spośród ludzi kierujacych pracami Sejmu Wielkiego jedynie Hugo Kołłątaj opowiedział się otwarcie za przystapieniem króla do Targowicy i rozpoczęciem pertraktacji $z$ jej władzami. Jeśli nawet nie od razu, to po pewnym czasie również pozostali przywódcy sejmowi uznali jednak, że w obliczu przegranej wojny jedynie król, wykorzystujacc dawną znajomość z Katarzyną II, zdoła ocalić niektóre reformy Sejmu Wielkiego i oddalić widmo nowego rozbioru grożącego Rzeczypospolitej ${ }^{46}$. Szybko okazało się jednak, że nadzieje te całkowicie zawiodły, a ludzie zwiazani $z$ obozem reform niemal natychmiast $z$ dali sobie sprawę $z$ błędów politycznych popełnionych w ciagu kilkunastu miesięcy po uchwaleniu Konstytucji 3 maja. Już w końcu lipca 1792 r. Jerzy Michał Potocki, rozgoryczony napływajaccymi $z$ kraju doniesieniami, wystapił wobec starszego brata, marszałka wielkiego litewskiego Ignacego Potockiego $z$ gwałtowna krytyka całokształtu polskiej polityki zagranicznej w ostatnim czasie: „Że zdradziecko postąpiły Prusy, trzeba im było dawniej nie ufać,

${ }^{44}$ J. Potocki do Stanisława Augusta, Sztokholm 20 i 27 VII 1792, BPAU, rkps 1652, k. 208, 211. Por. też Z. Anu sik, Misja polska..., s. 129; oraz id e m, Rzeczpospolita wobec wojny..., s. 182.

${ }^{45}$ Warto $\mathrm{w}$ tym miejscu podkreślić, że w obliczu interwencji rosyjskiej załamał się względnie jednolity do tej pory front polityczny przywódców stronnictwa patriotycznego. Hugo Kołłątaj np. od poczatku (podobnie jak Stanisław August) nie wierzył w skuteczność oporu i radził szukać porozumienia $z$ dworem petersburskim na bazie zaoferowania korony polskiej wnukowi cesarzowej. Ignacy i Stanisław Kostka Potoccy również nie wykluczali porozumienia $z$ Rosja, ale chcieli pertraktować na (w miarę możliwości) równoprawnych warunkach, w obliczu zdecydowanego oporu stawianego przez armię polską. Stanisław Małachowski wierzył zaś w dobre przygotowanie wojskowe Rzeczypospolitej i liczył na końcowy sukces w starciu $z$ interwencyjnymi armiami imperatorowej. Por. Z. Anusik, Kontrowersje wokół składu..., s. 116.

${ }^{46}$ Por. J. Łojek, Geneza i obalenie..., s. 408-417; Z. Anusik, Rzeczpospolita wobec wojny..., s. 183. 
kiedy zwodziły Szwecję, nie trzeba im było dać się prowadzić za nos. Trzeba było, robiąc traktat odstąpić Gdańska, a nie na pół rzeczy robić. Po Konstytucji 3 Maja trzeba było posłać do Rosji ambasadora, a nie romansowych używać zabaw"47. Tydzień później Jerzy Potocki pisał ponownie do Ignacego: „Szczerze bratu wyznaję, sami się zgubiliśmy przez politykę naszą... rzeczy by szli lepiej, żebyśmy otwarcie karali zdrajców" ${ }^{\prime 4}$. Co warte podkreślenia, do podobnych wniosków doszedł też Władysław Smoleński. Jego zdaniem sejm nie podjął żadnych kroków w celu zabezpieczenia swego dzieła przed knowaniami wewnętrznymi i działaniami wrogów zewnętrznych. Postępowanie $z$ emigrantami było chwiejne i pobłażliwe. Król bardziej szkodził sprawie niż pomagał. Żadnych kroków nie podjęto też w celu przygotowania kraju do ewentualnej wojny. Uchwalone zaś 16 kwietnia 1792 r. środki obrony były zdecydowanie spóźnione ${ }^{49}$. „Przerzucał się Stanisław August [w kwestii rokowań z Rosją - przyp. Z.A.] na nowe manowce złudzeń, po których, mając władzę niemal dyskrecyonalna, mógł błądzić do woli. Ciężko zawinił sejm, że uwierzył wygłoszonemu przez niego na posiedzeniu 22 maja r. 1792 frazesowi: "ufajcie! Gdy zajdzie potrzeba ofiary z życia mego, nie będę go szczędził"; nieroztropnie postapił, że limitując się, losy kraju złożył w ręce człowieka, który nie był bez zalet, lecz do roli kierowniczej nie dorósł"50.

W ciagu kilku miesięcy po przystapieniu króla do konfederacji targowickiej rozeszły się też, tym razem bezpowrotnie, drogi Stanisława Augusta i przywódców sejmowych. W pełni uzasadniony wydaje się bowiem pogląd Andrzeja Zahorskiego, który tak oto przedstawił to, co wydarzyło się w tym czasie: „król, przystępując do Targowicy, próbował ocalić kraj przed nowym podziałem, wracajac pod protektorat rosyjski. To wyjście było aprobowane przez przywódców sejmu, ale okazało się, że politycznie Polacy zbłądzili. Rosja bowiem szybko zorientowała się w nicości Targowicy i pojęła, że wobec powszechnej nienawiści do niej i powszechnym żądaniu pełnej niepodległości, rządy rosyjskie nad Polską nie mogą utrzy-

47 J. Potocki do I. Potockiego, Sztokholm 20 VII 1792, AGAD, APP nr 227, s. 463. Por. też Z. Anusik, Misja polska..., s. 130; oraz idem, Kontrowersje wokół składu..., s. 108.

48 J. Potocki do I. Potockiego, Sztokholm 27 VII 1792, AGAD, APP nr 227, s. 464. Por. też Z. Anusik, Misja polska..., s. 130; oraz idem, Kontrowersje wokół składu..., s. 108.

49 Por. W. S moleń ski, Ostatni rok Sejmu..., s. 420-423.

50 Ibidem, s. 427. 
mać się w oparciu o konfederatów. W tej sytuacji decyduje się Katarzyna na drugi podział Polski"51.

W obliczu przesądzonego już rozbioru, przygotowując antyrosyjski zryw niepodległościowy, przywódcy stronnictwa patriotycznego, którzy znaleźli schronienie na emigracji w Saksonii przystapili do opracowania słynnego później dzieła pt. O ustanowieniu i upadku konstytucji polskiej 3 maja. Obarczając Stanisława Augusta odpowiedzialnością za upadek dzieła sejmowego, Ignacy i Stanisław Kostka Potoccy, Franciszek Salezy Dmochowski oraz Hugo Kołłątaj wyparli się swojego udziału w powołaniu do Straży Praw zdeklarowanych stronników Rosji. Zarzucając królowi zbyt daleko posunięta kompromisowość w obsadzie najwyższych urzędów państwowych, byli przywódcy stronnictwa patriotycznego pisali: „Jest to cechą słabych umysłów nie móc się całkowicie wyrzec zastarzałych nałogów. Bojaźliwa ich polityka szuka zawsze, tak w jednej, jak w drugiej stronie zachować przyjaźń i oparcie, aby w zdarzeniu właściwym im, zmienność łatwy wszędzie znalazła przystęp. I tak głaskaja występek, choć są za cnota, aż zbrodnia połączeni ku cnocie niby wzdychaja" 52 . Oceniając politykę zagraniczna króla w okresie po uchwaleniu Konstytucji 3 maja, autorzy cytowanego działa zarzucaja Stanisławowi Augustowi jedynie to, że w załatwianiu spraw zagranicznych „przenosił małe sposoby, ciemne intrygi, drobna gabinetów czynność, trwożliwą ostrożność, podłe nawet uleganie, nad dzielne środki, które by jedynie naród kruszący jarzmo obcej przemocy zbawić mogły" ${ }^{33}$. Nasuwa się w tym miejscu zasadnicze pytanie. Dlaczego byli przywódcy Sejmu Wielkiego ani słowem nie wspomnieli o zaprzepaszczeniu przez króla szansy na nawiązanie rokowań $z$ dworem petersburskim i odwrócenie groźby rosyjskiej interwencji w wewnętrzne sprawy Rzeczypospolitej? Otóż odpowiedź wydaje się oczywista. Nie sposób było przygotowywać antyrosyjskie powstanie i wyjaśniać równocześnie rodakom, że drugi rozbiór doszedł do skutku prawdopodobnie dlatego, że tak $z$ winy króla, jak i przywódców Sejmu Wielkiego nie wykorzystano szansy na pokojowe uregulowanie stosunków $z$ potężnym sąsiadem ze wschodu ${ }^{54}$.

51 A. Zahorski, Spór o Stanisława Augusta, Warszawa 1988, s. 448.

52 Cyt. wg ibidem, s. 58. Por. też Z. Anusik, Kontrowersje wokół składu..., s. $108-109$.

${ }^{5}$ O ustanowieniu upadku konstytucji polskiej 3 maja, t. II, Lwów 1793, s. 101-102.

${ }^{54}$ Por. Z. Anu sik, Kontrowersje wokół składu..., s. 109; i d e m, Rzeczpospolita wobec wojny..., s. 184; id e m, Stosunki polsko-pruskie..., s. 230. 
W tym miejscu nasuwa się jednak od razu kolejna wątpliwość. Dlaczego sprawa udziału przywódców sejmowych w zamierzonym (przynajmniej w pierwszych tygodniach po uchwaleniu Konstytucji 3 maja) zwrocie politycznym w kierunku dworu petersburskiego nie znalazła odpowiedniego odzwierciedlenia w przygotowanej przez króla pod nazwiskiem Mikołaja Wolskiego „Obronie Stanisława Augusta"? Dlaczego, rozpisując się szeroko we wszystkich możliwych przewinach przywódców „stronnictwa pruskiego”, nie postawił im ostatni władca Rzeczypospolitej zarzutu (jakże ważnego ze względu na przyszłą opinię o ostatnich latach jego panowania) nakłaniania go do powrotu pod (być może nieco złagodzony) protektorat rosyjski? Otóż wydaje się, że nie uczynił tego $z$ tych samych powodów, które kazały jego adwersarzom zataić własny współudział w kształtowaniu kierunków polityki zagranicznej i wewnętrznej Rzeczypospolitej w ostatniej fazie obrad Sejmu Wielkiego. Dożywając swoich dni jako rezydent, pozostający na utrzymaniu dworu petersburskiego, nie mógł Stanisław August oświadczyć wszem wobec (a tonował ze względów cenzuralnych również inne swoje wypowiedzi), że w okresie, kiedy odgrywał w Polsce naprawdę samodzielna rolę polityczna, robił wszystko, co w jego mocy, aby do przywrócenia wpływu Rosji na sprawy Rzeczypospolitej po prostu nie dopuścić. W ten oto sposób (ze względów czysto taktycznych) obie strony konfliktu postarały się o to, by gruntownie zagmatwać i zataić przed następnymi pokoleniami problem stosunku polskich elit politycznych do nawiązania rokowań $z$ dworem petersburskim, problem kluczowy z punktu widzenia interesów i międzynarodowego położenia Rzeczypospolitej w ostatniej fazie obrad Sejmu Wielkiego ${ }^{55}$.

Na zakończenie warto wyraźnie podkreślić, że o niepowodzeniu polskiej polityki zagranicznej w ostatniej fazie obrad Sejmu Wielkiego zadecydowało wiele różnorakich czynników. Tylko jednym $z$ nich było niechętne Polsce i dwuznaczne stanowisko dworu berlińskiego. Jeszcze w początkach 1792 r. przyszły los Rzeczypospolitej wcale nie był przesądzony. Katarzyna II zdecydowała się wysłać swoje wojska do Polski dopiero wtedy, kiedy upewniła się o jej całkowitej izolacji na arenie międzynarodowej. To nie przychylna rosyjskim zamierzeniom postawa Prus, ale wieści o śmierci Leopolda II,

${ }^{55}$ Por. M. Wols ki, op. cit., passim; A. Zahors ki, op. cit., s. 65-112 (tu streszczenie zarzutów stawianych przez króla przywódcom Sejmu Wielkiego); Z. A nusik, Kontrowersje wokót składu..., s. 109-110; id e m, Stosunki polsko-pruskie..., s. 230-231; id e m, Rzeczpospolita wobec wojny..., s. 184-185. 
śmierci Gustawa III i francuskiej deklaracji wojennej wobec Austrii wywarły decydujący wpływ na ostateczną decyzję dworu petersburskiego. Decyzję, co należy wyraźnie zaznaczyć, podjęta pod wpływem zachęt i obietnic bez pokrycia składanych w Petersburgu przez twórców osławionej konfederacji targowickiej ${ }^{56}$. Jest sprawą oczywistą, że zarówno król, jak i przywódcy sejmowi popełnili wiele istotnych błędów politycznych. Najważniejszym z nich było przekonanie, że Rzeczpospolita może osiagnąć swoje cele polityczne, zachowując jednocześnie neutralność wobec rozgrywających się u jej granic konfliktów. Dostrzegano jednak w Warszawie, że kolejne pacyfikacje pogarszaja międzynarodowe położenie państwa polsko-litewskiego. Bardzo szybko zdano też sobie sprawę $z$ tego, że prędzej czy później trzeba będzie poszukać porozumienia $z$ dworem petersburskim. Przywódcy sejmowi, którzy sami podsunęli Stanisławowi Augustowi pomysł rozpoczęcia rokowań $z$ imperatorowa, nie wykazali jednak stanowczości i konsekwencji w tej sprawie (podobnie zreszta jak $\mathrm{w}$ wielu innych, istotnych $z$ punktu widzenia bezpieczeństwa państwa kwestiach) i w następnych miesiącach poddali się wraz z królem iluzorycznym (a tak bardzo leżącym w charakterze Polaków) nadziejom na znalezienie jakiegoś pośredniego wyjścia $z$ sytuacji, w jakiej znalazła się Rzeczpospolita po wygaśnięciu pomyślnej dla niej koniunktury na arenie międzynarodowej. Fatalnie rozegrano też wojnę z Rosją w 1792 r. Brak poważniejszego oporu ze strony armii polskiej uniemożliwił de facto rozpoczęcie jakichkolwiek poważnych negocjacji pokojowych. Słabość militarna Rzeczypospolitej i szybki

${ }^{56}$ Podobnie uważał J. Łojek, który twierdził, że: „Stanowisko dworu petersburskiego wobec Konstytucji 3 maja było przez wiele miesięcy nie sprecyzowane i chwiejne, że w łonie decydujacych sfer dworskich trwały zaciekłe spory o politykę wobec Rzeczypospolitej i że ostateczna decyzja o interwencji zapadła dopiero na kilka tygodni przed jej wprowadzeniem w życie". Por. idem, Geneza i obalenie..., s. 172-174; ide m, Misja Debolego..., s. 96-138. Emanuel Rostworowski był natomiast przekonany o tym, że nie istniały szanse porozumienia $z$ dworem petersburskim, ponieważ Katarzyna II nie dopuszczała do siebie myśli o możliwości wyemancypowania się Rzeczypospolitej spod jej kurateli i miała w tym względzie poparcie swoich wszystkich (bez żadnego wyjątku) doradców. Por. id e m, Maj $1791 \ldots$, s. 28. Nie zgadzając się $z$ tym twierdzeniem, któremu przeczą cytowane w tym tekście, wiarygodne przekazy źródłowe, dodam tylko, że w moim przekonaniu bardzo długo istniały realne szanse na wynegocjowanie takiego porozumienia z dworem petersburskim, które gwarantowałoby zachowanie przynajmniej części reform ustrojowych przeprowadzonych przez Sejm Czteroletni. Rozmowy z Rosja należało jednak rozpoczą́ jeszcze przed wybuchem wojny. Uważam również, że rozmowy takie nie byłyby w ogóle konieczne, gdyby sejm podją przygotowania do obrony kraju nie w kwietniu 1792, a wiosną roku 1789. 
marsz wojsk rosyjskich w kierunku Warszawy były bowiem kolejnymi, decydujacymi tym razem, argumentami w rozgrywce między zwolennikami i przeciwnikami wojny na dworze petersburskim ${ }^{57}$. Realizacja planów podsuwanych cesarzowej przez drapieżna klikę Zubowa, połączona $z$ ofensywą dyplomatyczną dworu berlińskiego, przesądziła zaś ostatecznie o tym, że Katarzyna II zaakceptowała, kiełkujący w jej otoczeniu od momentu rozpoczęcia wojny, pomysł dokonania drugiego rozbioru Polski.

\section{Bibliografia}

\section{$\dot{Z}_{\text {RódeA ARCHIWALNE }}$}

Archiwum Główne Akt Dawnych w Warszawie (AGAD)

Archiwum Publiczne Potockich (APP) nr 227.

Biblioteka Naukowa PAU i PAN w Krakowie (BPAU)

rkps 1652, 1653.

Riksarkivet w Sztokholmie (RA)

Muscovitica vol. 451, 452, 453.

Polonica vol. 229.

\footnotetext{
${ }^{57}$ Warto w tym miejscu raz jeszcze przypomnieć, że Aleksander A. Bezborodko i Aleksander R. Woroncow byli przeciwni wojnie $z$ Rzecząpospolitą, gdyż byli przekonani o tym, że będzie ona kosztowna i długotrwała. Gdyby państwo polsko-litewskie dysponowało 100-tysięczna, dobrze uzbrojona, wyekwipowaną i gotowa do walki armia, ich zdanie $z$ pewnościa przeważyłoby $\mathrm{w}$ radzie Katarzyny II i do wojny najpewniej w ogóle by nie doszło. Dodajmy także, że nawet w czasie trwania działań wojennych istniały duże szanse na rozpoczęcie rozmów $z$ dworem petersburskim. Gdyby armie Rzeczypospolitej stawiły bardziej zdecydowany opór Rosjanom, gdyby po miesiącu wojny wojska cesarzowej musiały toczyć zacięte walki w okolicach Mińska, Słucka i Żytomierza, Bezborodko i jego adherenci zyskaliby dodatkowy argument przemawiający za przyjęciem propozycji zawartych w liście Stanisława Augusta do Katarzyny II. Dobrze zorientowany w petersburskich stosunkach Curt von Stedingk uważał, że jedyna szansą ocalenia Polski będzie zdanie się na łaskę cesarzowej lub też stawienie jej wojskom zaciętego oporu. Król i przywódcy sejmowi wybrali droge pośrednią. Podjęli walkę, ale zbyt szybko przestali wierzyć w możliwość odniesienia zwycięstwa i skapitulowali w chwili, kiedy istniały jeszcze szanse na kontynuowanie wojny, której przedłużenie o kilka tygodni mogło skłonić cesarzową do wyrażenia zgody na rozpoczęcie negocjacji pokojowych. Był to fatalny błąd polityczny, który okazał się w konsekwencji początkiem końca pierwszej Rzeczypospolitej.
} 


\section{$\dot{Z}_{\text {RÓDEA DRUKOWANE }}$}

Głos Jaśnie Wielmożnego Jegomości Tadeusza Kościałkowskiego z Zyndranów, starosty Czotyrskiego, posła Wiłkomierskiego na sesyi seymowey dnia 6 Grudnia 1791 r. miany, Warszawa [1791].

Głos Jego Królewskiej Mości dnia 21 maja roku 1792, [Warszawa 1792].

Kalinka W., Ostatnie lata panowania Stanisława Augusta, wyd. 2, cz. 2 (Dokumenta do historyi drugiego i trzeciego podziału), Kraków 1891.

O ustanowieniu upadku konstytucji polskiej 3 maja, t. II, Lwów 1793.

Ostatni poset polski do Porty Ottomańskiej. Akta legacji stambulskiej Franciszka Piotra Potockiego, wyd. K. Waliszewski, t. I, Paris 1894.

Rok nadziei, rok klęski. Z korespondencji Stanisława Augusta z posłem polskim w Petersburgu Augustynem Deboli, wyd. J. Łojek, Warszawa 1974.

Stanislas Poniatowski et Maurice Glayre. Correspondance relative aux partages de la Pologne, wyd. E. Mottaz, Paris 1897.

Volumina legum, t. IX, Kraków 1889.

Wolski M., Obrona Stanisława Augusta, wyd. B. Zaleski, „Rocznik Towarzystwa Historyczno-Literackiego w Paryżu”, R. 1867, Poznań 1867.

\section{Opracowania}

Anusik Z., Czy dwór berliński proponował Szwecji udział w drugim rozbiorze Polski? Przyczynek do dziejów stosunków politycznych pomiędzy Sztokholmem, Berlinem $i$ Warszawa w latach 1789-1792, [w:] Oświeceni wobec rozbiorów Polski, red. J. Grobis, Łódź 1998, s. 43-63.

Anusik Z., Dyplomacja szwedzka wobec kryzysu monarchii we Francji $w$ latach 1787-1792, Łódź 2000.

Anusik Z., Kontrowersje wokół składu personalnego Straży Praw. Wpływ uwarunkowan międzynarodowych na sytuacje wewnętrzna $w$ Rzeczypospolitej w ostatniej fazie obrad Sejmu Czteroletniego, [w:] 200 lat Konstytucji 3 Maja. Materiały z konferencji naukowej, red. M. Pawlak, Bydgoszcz 1992, s. 93-116.

Anusik Z., Między Warszawa, Sztokholmem i Petersburgiem. Geneza rosyjskiej interwencji $w$ Polsce $w 1792$ r. $w$ świetle korespondencji ambasadora szwedzkiego w Petersburgu Curta von Stedingka, [w:] Przełomy w historii. XVI Powszechny Zjazd Historyków Polskich (Wrockaw 15-18 września 1999 roku). Pamiętnik, t. II, cz. 1, Toruń 2000, s. 255-276.

Anusik Z., Misja polska w Sztokholmie w latach 1789-1795, Łódź 1993.

Anusik Z., O polska koronę. Dwór sztokholmski wobec kwestii sukcesji tronu w Polsce $w$ dobie Sejmu Czteroletniego, [w:] Studia i materiały $z$ dziejów nowożytnych, red. K. Matwijowski, S. Ochmann-Staniszewska, Prace historyczne XIII, Wrocław 1995, s. 147-167.

Anusik Z., O szwedzki alians. Karta z dziejów stosunków politycznych pomiędzy Sztokholmem a Warszawa $w$ dobie Sejmu Czteroletniego, „Acta Universitatis Lodziensis", Folia Historica 57, 1996, s. 77-106. 
Anusik Z., Organizacja i funkcjonowanie polskiej służby zagranicznej $w$ latach 1764-1792 (próba nowego spojrzenia), „Acta Universitatis Lodziensis”, Folia Historica 58, 1996, s. 49-82.

Anusik Z., Rokowania o polsko-szwedzki traktat sojuszniczy w 1790 roku, „Zapiski Historyczne" 1996, t. LXI, z. 2-3, s. 21-44.

Anusik Z., Rzeczpospolita wobec wojny wschodniej (1787-1792) i wojny szwedzko-rosyjskiej (1788-1790), [w:] Polska wobec wielkich konfliktów w Europie nowożytnej. $Z$ dziejów dyplomacji i stosunków międzynarodowych $w$ XV-XVIII wieku, red. R. Skowron, Kraków 2009, s. 145-186.

Anusik Z., Stosunki polsko-pruskie $w$ dobie Sejmu Czteroletniego. Kilka refleksji w zwiazku z książka Macieja Kucharskiego, „Przegląd Nauk Historycznych” 2003, R. II, nr 1 (3), s. 207-233.

Anusik Z., Szwedzki rywal Fryderyka Augusta. Gustaw III wobec projektów sukcesji tronu $w$ Polsce w latach 1790-1792, „Rocznik Łódzki” 1997, t. XLIV, s. 89-115.

Anusik Z., Wznowienie stosunków dyplomatycznych polsko-szwedzkich u progu obrad Sejmu Czteroletniego, „Acta Universitatis Lodziensis”, Folia Historica 49, 1993, s. 67-95.

Anusik Z., Stroynowski A., Rybiński Józef Ignacy Tadeusz, [w:] Polski słownik biograficzny, t. XXXIII, Wrocław-Warszawa-Kraków 1991-1992, s. 334-338.

Askenazy S., Przymierze polsko-pruskie, wyd. 3, Warszawa 1918.

Czeppe M., Orman-Michta E., Sołtyk Stanisław, [w:] Polski słownik biograficzny, t. XL, Warszawa-Kraków 2000-2001, s. 424-431.

Dembiński B., Rosya a rewolucya francuska, Kraków 1896.

Grochulska B., Potocki Stanisław Kostka, [w:] Polski słownik biograficzny, t. XXVIII, Wrocław 1984-1985, s. 158-170.

Homola I., Kossakowski Józef Dominik, [w:] Polski słownik biograficzny, t. XIV, Wrocław-Warszawa-Kraków 1967-1968, s. 274-276.

Kalinka W., Polityka dworu austryackiego w sprawie konstytucyi 3 maja, Kraków 1873.

Kalinka W., Sejm Czteroletni, wyd. 4, t. I-II, Kraków 1895-1896.

Kądziela Ł., Rzewuski Kazimierz, [w:] Polski słownik biograficzny, t. XXXIV, Wrocław-Warszawa-Kraków 1992-1993, s. 115-127.

Konopczyński W., Polska a Szwecja. Od pokoju oliwskiego do upadku Rzeczypospolitej 1660-1795, Warszawa 1924.

Krakowski B., Kościałkowski Tadeusz, [w:] Polski słownik biograficzny, t. XIV, Wrocław-Warszawa-Kraków 1967-1968, s. 396-397.

Kucharski M., Działalność dyplomacji polskiej $w$ Berlinie $w$ latach 1788-1792, Katowice 2000.

Leśnodorski B., Dzieło Sejmu Czteroletniego (1788-1792). Studium historyczno- prawne, Wrocław 1951.

Lord R.H., Drugi rozbiór Polski, Warszawa 1973.

Łojek J., Geneza i obalenie Konstytucji 3 maja. Polityka zagraniczna Rzeczypospolitej 1787-1792, Lublin 1986. 
Łojek J., Misja Debolego w Petersburgu w latach 1787-1792. Z dziejów stosunków polsko-rosyjskich w czasach Sejmu Czteroletniego, Wrocław 1962.

Michalski J., „Warszawa”, czyli o antystołecznych nastrojach $w$ czasach Stanisława Augusta, [w:] Warszawa XVIII wieku, z. 1, Warszawa 1972, s. 9-78.

Michalski J., Dyplomacja polska w latach 1764-1795, [w:] Historia dyplomacji polskiej, t. II (1572-1795), red. Z. Wójcik, s. 483-707.

Nawrot D., Działania dyplomacji polskiej w Wiedniu w latach 1788-1792, Katowice 1999.

Nawrot D., Próba reorientacji polskiej polityki zagranicznej w marcu 1792 r., [w:] Dyplomacja. Polityka. Prawo. Ksiega pamiatkowa ofiarowana Profesorowi Henrykowi Kocójowi w siedemdziesiąta rocznice urodzin, red. I. Panic, Katowice 2001, s. 64-73.

Rostworowski E., Jelski Konstanty, [w:] Polski słownik biograficzny, t. XI, Wrocław-Warszawa-Kraków 1964-1965, s. 154-155.

Rostworowski E., Maj 1791 - maj 1792. Rok monarchii konstytucyjnej, Warszawa 1985

Rostworowski E., Ostatni król Rzeczypospolitej. Geneza i upadek Konstytucji 3 maja, Warszawa 1966.

Rostworowski E., Potocki Stanisław Szczesny, [w:] Polski słownik biograficzny, t. XXVIII, Wrocław 1984-1985, s. 183-202.

Smoleński W., Konfederacja targowicka, Kraków 1903.

Smoleński W., Ostatni rok Sejmu Wielkiego, wyd. 2, Kraków 1897

Stroynowski A., Patriotyczne wystapienia opozycji na sejmie 1778 r., „Acta Universitatis Lodziensis", Folia Historica 19, 1984, s. 173-180.

Stroynowski A., Sejmowa opozycja antykrólewska $w$ czasach Rady Nieustajacej (kryteria klasyfikacji), „Acta Universitatis Lodziensis”, Folia Historica 18, 1984, s. $17-27$.

Szczygielski W., Krytyka parlamentarna Rady Nieustajacej w poczatkach obrad Sejmu Wielkiego a problem konstytucyjnej reformy władz wykonawczych państwa, „Przegląd Nauk Historycznych” 2003, R. II, nr 2 (4), s. 67-110.

Szczygielski W., Oświecony elitaryzm w Polsce, „Zeszyty Naukowe Uniwersytetu Łódzkiego", Ser. I, z. 4, 1976, s. 111-120.

Szczygielski W., Referendum trzeciomajowe. Sejmiki lutowe 1792 roku, Łódź 1994.

Tomkowicz S., Z wieku Stanisława Augusta, Kraków 1882.

Wojakowski J., Straż Praw, Warszawa 1982.

Zahorski A., Spór o Stanisława Augusta, Warszawa 1988.

Zielińska Z., Rzewuski Seweryn, [w:] Polski słownik biograficzny, t. XXXIV, Wrocław-Warszawa-Kraków 1992-1993, s. 138-151.

Złomska M., Miaskowski Józef, [w:] Polski słownik biograficzny, t. XX, Wrocław 1975, s. 541-542.

Złomska M., Olędzki (Olendzki) Stanisław, [w:] Polski słownik biograficzny, t. XXIII, Wrocław 1978, s. 796-797. 
ZBigniew AnUsik

\section{The Commonwealth of Poland towards Russia in the final stage of the Great Diet (1791-1792)}

W hen the Constitution was ratified on May 3, 1791, establishing good relations with Russia was the most important issue for the security of the Commonwealth. As leaders of the Great Diet noticed that prosperous situation in the Polish-Lithuanian state's international relations was ending, they suggested Stanisław August to turn to Russia. Because of their initiative, the king introduced several members of the St. Petersburg court to the Guardians of the Laws. Yet, it did not reorient Polish foreign policy. Having strengthened his position, Stanisław August was delaying direct talks with the empress. He was convinced, that to avoid Russian intervention in the Commonwealth's internal affairs, one should not provoke Russians and appease any internal conflicts. That assumption turned to be wrong, though. Contrary to the views of the vast majority of Polish historians, who believed that Russian intervention in Poland was predetermined, the St. Petersburg court was divided, when it came to the policy on the Polish-Lithuanian state. Some advisers of Catherine II believed, that without a final agreement with German courts, one should not start a war with the Commonwealth, because it would be hard, long-lasting and costly. Yet, views of Polish malcontents and empress's favorite, Platon A. Zubov, were taken into account, and a military operation was launched, without looking at Vienna and Berlin's position. A passive diplomacy turned out to be a fatal mistake of the Polish king and his advisers. The concept of a limited warfare was equally wrong. The weak resistance of the Polish army strengthened the position of the empress's favorite. When Stanisław August's letter to Catherine II arrived at St. Petersburg, already in the course of war, at the Russian court a group of war opponents took a final attempt to stop hostilities, and start negotiations with the Commonwealth's ruler. However, successes of empress's troops, that rapidly moved towards Warsaw after the withdrawing Poles, favored supporters of an armed intervention. The king and his advisers ceased to believe in the possibility of victory too soon, and capitulated at the time, when there was still a chance to continue the war, a prolongation of which by several weeks might have prompted the empress to start peace negotiations. It was a great political mistake, which turned out to be the beginning of the end of the First Republic.

Keywords: Great Diet, Constitution of May 3, Guardians of the Laws, foreign policy of the Commonwealth, Russian-Polish relations in 1791-1792. 